\title{
An Epigravettian hypogeal site in the Grotta del Fiume Cave at Frasassi (northeastern Apennines, Italy): Environmental and geochronologic assessments
}

\author{
Alessandro Montanari (D ${ }^{1 *}$, Artur Adamek ${ }^{2}$, Angelo Curatolo ${ }^{3}$, Marco P. Ferretti (iD ${ }^{4}$, \\ Maurizio Mainiero (D) ${ }^{5}$, Sandro Mariani ${ }^{6}$, David McGee (iD) ${ }^{7}$, Gaia Pignocchi (1D) ${ }^{8}$, \\ and Stefano Recanatini ${ }^{9}$
}

\begin{abstract}
${ }^{1}$ Osservatorio Geologico di Coldigioco, Cda. Coldigioco 4, 62021 Apiro, Italy
${ }_{2}^{2}$ Faculty of Mining Surveying and Environmental Engineering, AGH University of Science and Technology, al. Mickiewicza 30, 30-059 Kraków, Poland ${ }^{3}$ GECO srl. Geological Research Company, Via Osoppo 38, 60015 Falconara Marittima (AN), Italy

${ }^{4}$ Università di Camerino, Sezione di Geologia, Via Gentile III da Varano, 27, 62032 Camerino, Italy

${ }^{5}$ Studio Geologico, Via XXIX Settembre 2/O, 60122 Ancona, Italy

${ }^{6}$ Gruppo Speleologico CAI Fabriano, Via Alfieri 9, 60044 Fabriano, Italy

${ }^{7}$ Department of Earth, Atmospheric, and Planetary Sciences, Massachusetts Institute of Technology, Cambridge, Massachusetts 02142, USA

${ }^{8}$ Archeologist, Via Cagli 5, 60129 Ancona, Italy

${ }^{9}$ Gruppo Speleologico Marchigiano, Via Veneto 10, 60122 Ancona, Italy
\end{abstract}

\begin{abstract}
In the late fall of 1986, a team of cavers from the Gruppo Speleologico Marchigiano of Ancona reported to the regional Archeological Superintendence their discovery in a room of the Grotta del Fiume Cave (Marche region of central Italy) of archeological finds such as the charcoal remains of a bonfire, a number of ibex bones, and four chert artifacts. However, since the discovery and archival of all this material, no further research or focused studies were carried out about this important archeological site. Therefore, we engaged in a thorough re-examination of this site by mapping this part of the Grotta del Fiume Cave with modern surveying approaches, including terrestrial laser scanner and ground penetrating radar. Moreover, we have radiocarbon dated a few ibex bones and also charcoal samples from the main fireplace and other smaller charcoal deposits we found scattered around the room's floor. The chert artifacts were examined in detail and their typology classified accordingly. $\mathrm{U}$-Th dating of calcite from speleothems helped us reconstruct this hypogeal environment at the time it was frequented by man. We also studied a puzzling deposit of speleothem crust slabs piled up in a corner of the cave, which may represent a funeral earthen mound. All in all, the absence of artifacts other than the four chert blades, the few ibex bones, the one main fireplace and three other minor charcoal deposits in the room, and the probable earthen mound located tens of meters underground from a now debris-sealed entrance, lead us to hypothesize that this cave room does not represent a residential dwelling but rather a worship place sporadically utilized by few representatives of a local Epigravettian hunter community.
\end{abstract}

Keywords: $\quad$ Frasassi caves, archeology, Paleolithic fireplace, Late Pleistocene Ibex, Epigravettian lithic industry Received 18 April 2020; Revised 11 May 2020; Accepted 11 May 2020

Citation: Montanari A., Adamek A., Curatolo A., Ferretti M.P., Mainiero M., Mariani S., McGee D., Pignocchi G. and Recanatini S., 2020. An Epigravettian hypogeal site in the Grotta del Fiume Cave at Frasassi (northeastern Apennines, Italy): Environmental and geochronologic assessments. International Journal of Speleology, 49 (2), 87-105. Tampa, FL (USA) ISSN 0392-6672 https://doi.org/10.5038/1827-806X.49.2.2324

\section{INTRODUCTION}

On November 15, 1986, while exploring the Grotta del Fiume Cave in the Frasassi Gorge (Marche region, northeastern Apennines of Italy), a team of cavers from the speleologic group Gruppo Speleologico Marchigiano (GSM) of Ancona, discovered a new room christened by them "Galleria dello Stambecco" (Gallery of the Steinbock), and here referred to as "Sala del
Fuoco" (Room of Fire). In this remote and difficultto-reach room, the cavers found a number of animal bones, the charcoal remains of a fireplace, and, most striking, the skull of a mountain goat or steinbock (Capra ibex; ibex from hereafter) set on the tip of a short stalagmite (Fig. 1). These finds were dutifully reported to the Archeological Superintendence of Marche on December 21 of the same year by Giuseppe Antonini, one of the discoverers and at the time 
President of the GSM of Ancona (Antonini, 1986). On October 30, 1987, Forestalp, a cooperative firm operating outdoor activities such as on-rope aerial jobs, of which Antonini was an executive member, terminated the survey of Galleria dello Stambecco (cf. Sala del Fuoco), and delivered to the Archeological Superintendence of Marche a report, which described in detail the techniques and methods used for surveying the site, and for drafting a map with the location of the various archeological finds. Forestalp's report emphasized that the cave was located no more than $10 \mathrm{~m}$ below the surface but the access to the outside at the end of a narrow tunnel was obstructed by debris. The report also reiterated the original hypothesis by Antonini (1986) that the cave did not represent a residential dwelling but rather a prehistoric place of worship. On November 15 of the same year, Forestalp (1987) asked permission from the Archeological Superintendence to carry out the recovery of archeological finds in Sala del Fuoco, which included: 1) "chert artifacts"; 2) "steinbock skulls and animal bones belonging to various individuals"; and 3) "fossilized charcoal pieces". Permission was granted by the chief superintendent on November 27 of the same year. Eventually, the recovered archeological material along with the Forestalp report was archived and stored away by the in-charge official of the Archeological Superintendence, on

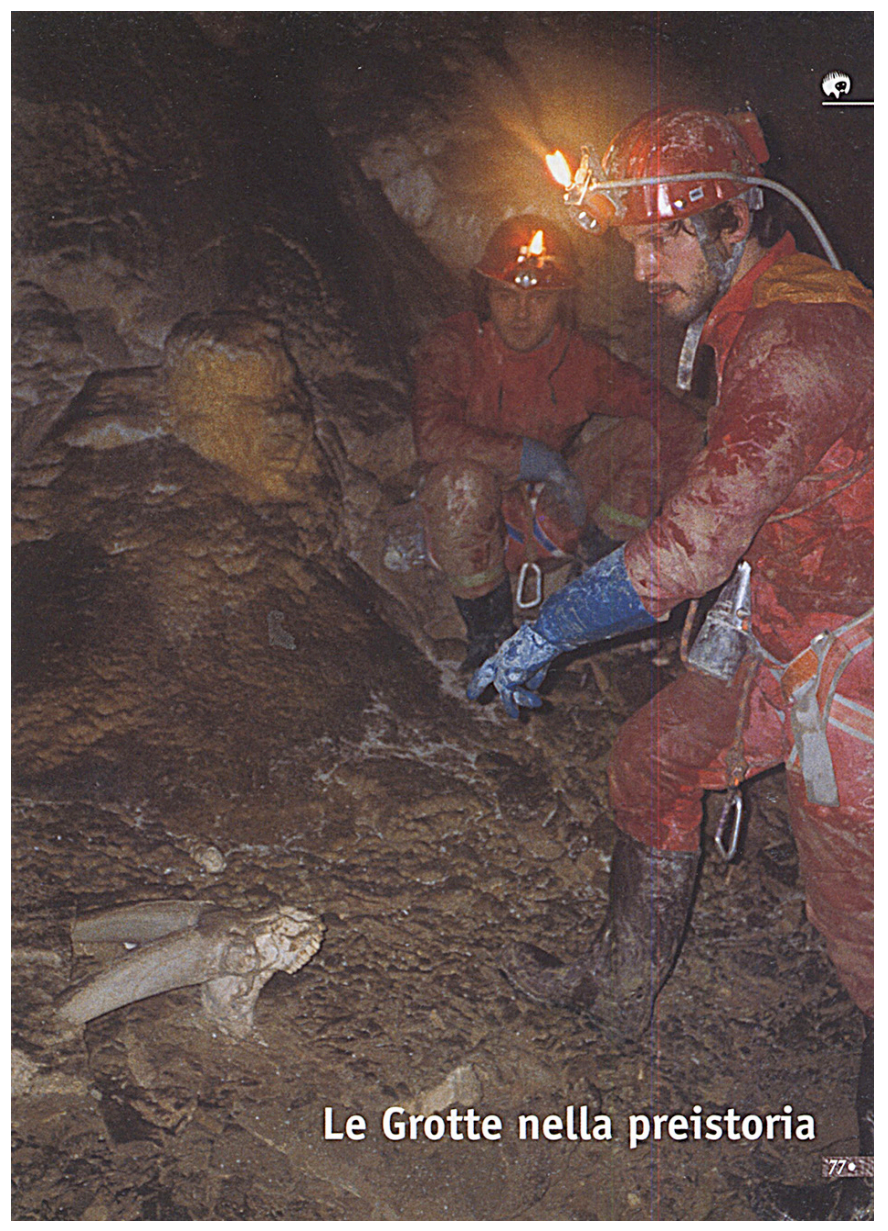

Fig. 1. The discovery of an ibex skull in "Sala dello Stambecco" (aka Sala del Fuoco) by a team of cavers from the Gruppo Speleologico Marchigiano in 1986. The head of the team, Giuseppe Antonini (Antonini, 1986), pictured crouched down in the background. Source: page 77 of the speleologic guide "Il mondo sotterraneo" (Parco Naturale della Rossa e di Frasassi, 2000).
January 29, 1990. Unfortunately, of all the material provided by Forestalp, only a box containing four chert artifacts is to be found today in the archive of the Archeological Superintendence. Regrettably, the map and photographs, the fireplace charcoal sample, the abundant bones, and the ibex skull(s) were not to be found anywhere in the archive, and no indication of where else they may have been stored was given to us by the archive's attendants.

Despite its importance, the discovery of Sala del Fuoco with its little archeological treasure was never publicized, and, as far as we know, no further scientific investigations were made nor published about this site. Twenty years after being discovered, we revisited this room while studying alluvial sediments (clay, sand, and gravel) often found in near-entrance sites in the Frasassi cave complex (e.g., Mariani, 2003; Pignocchi \& Montanari, 2016; Montanari et al., 2019). At about the same time, during a study involving radiocarbon dating of Holocene subfossil eels grounded at different heights above present water table in a remote inner region of the Grotta del Fiume Cave, we had the chance to have a sample of the fireplace charcoal radiocarbon dated with AMS by Klaas van der Borg (Utrecht University), a coauthor in Mariani et al. (2007). The charcoal yielded a radiocarbon age of 13,550 $\pm 90 \mathrm{yr}$ later calibrated at calendar age 16,646-16,046 yr cal. $\mathrm{BP}$ (Fig. 2), which was recently mentioned in a few abstracts (Pignocchi, 2015; Montanari et al., 2017) and in a conference proceedings volume (Pignocchi et al. 2018). Our preliminary date of $\sim 16.3 \mathrm{ka}$ for the fireplace and the associated chert artifacts in Sala del Fuoco represented one of the few radioisotopically dated evidence for an Epigravettian culture in this region of the northern Apennines (Broglio et al., 2005; Silvestrini et al., 2005, 2008), and one of the few dated archeological sites in Italy belonging to the Late Pleniglacial Stage (e.g., Ravazzi et al., 2007; Cremona, 2008; Mussi et al., 2008, and references therein). We therefore engaged in a thorough environmental study of this site including cartographic and terrestrial laser scanner (TLS) mapping, speleo-geomorphologic, and sedimentologic study of the Sala del Fuoco including a ground penetrating radar survey (GPR), speleothem

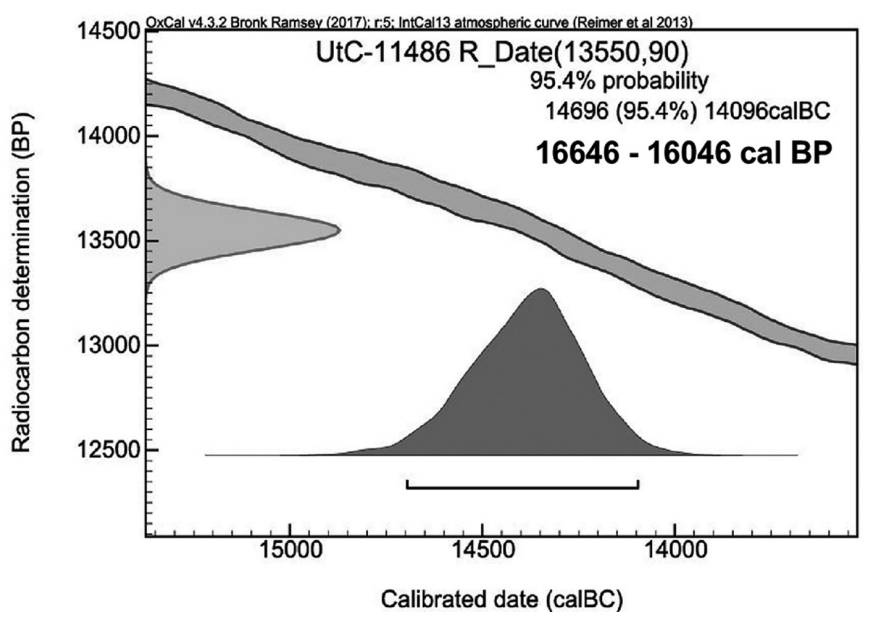

Fig. 2. Graphic output of 14C AMS analysis UtC-11486 of a charcoal sample from the main fireplace of Sala del Fuoco performed at Utrecht in 2006 (sample name: Eels_02\#DO202). Courtesy of Dr. K. van der Borg. 
U-Th dating, and ${ }^{14} \mathrm{C}$ AMS dating of ibex bones and charcoal samples from the main fireplace and from three other small charcoal deposits we found in different places in the cave room. We also studied, and wondered about, a puzzling deposit of speleothemic crust slabs piled up on one side of the room not far from the fireplace, which may represent an earthen mound.

\section{METHODS AND TECHNIQUES}

The topographic survey of the Sala del Fuoco room in the Grotta del Fiume cave was accomplished with a combination of closed and open polygonals, a method traditionally used in cave mapping. It consists in making a polygonal line along the perimetral walls of a cave room or through a narrow tunnel, taking measurements with a compass for reading horizontal angles (direction), clinometer for vertical ones (inclination), and measuring tape for determining distances (length). In our case we used a laser instrument called DISTOX2. It is a Leica Disto X310 modified with an upgrade kit, which includes a 3-axis compass, a clinometer, and a Bluetooth connection. For the 3D survey of Sala del Fuoco we used a Terrestrial Laser Scanner FARO FOCUS 3D for acquisition data, and the FARO SCENE software for elaborating the acquired point clouds.

Ground-penetrating radar (GPR) is a non-destructive geophysical method that uses radar pulses to image the subsurface using electromagnetic radiation in the microwave band (UHF/VHF frequencies) of the radio spectrum, and detects the reflected signals from subsurface structures. For the survey of Sala del Fuoco we used a ZOND 12E GPR RADAR with an 1.5 $\mathrm{Ghz}$ antenna and signal acquisition at $100 \mathrm{~ns}$.

About 200 high-resolution photographs were taken in Sala del Fuoco using a CANON EOS 5D MARK II digital camera to document speleo-geomorphologic and environmental features, and close-up pictures of sampled sites. After locating the sampled sites on the map, and having photographed them, sampling proceeded using tweezers for picking up charcoal fragments, finger picking to collect bones, and a trowel to collect loose sediment.

Radiocarbon AMS dating of charcoal, bone, and speleotemic calcite samples was performed at the Beta Analytic Laboratory in Miami, (USA), using sample preparation and pretreatment routinely applied for these materials by this laboratory.

Samples of speleothemic calcite were collected using hammer and chisel, and later cut in centimetric subsamples with a wet diamond rock saw for U-Th dating in the McGee Laboratory at Massachusetts Institute of Technology. We used the U-Th chemistry procedure of Edwards et al. (1987) to prepare the samples. This procedure included addition of a calibrated ${ }^{229} \mathrm{Th}^{233} \mathrm{U}-{ }^{236} \mathrm{U}$ tracer solution, dissolution, iron co-precipitation, and anion exchange chromatography in order to isolate the small amounts of $U$ and $T h$ from the calcium carbonate. The $U$ and Th isotopes were measured using the Nu Plasma II multicollector-inductively coupled plasma-mass spectrometer (MC ICP-MS) with enhanced sensitivity (ES) interface in the McGee Laboratory. U-Th ages were calculated using the decay constants determined by Jaffey et al. (1971) for ${ }^{238} \mathrm{U}$ and Cheng et al. (2013) for ${ }^{234} \mathrm{U}$ and ${ }^{230} \mathrm{Th}$. Corrections for initial ${ }^{230} \mathrm{Th}$ assumed an initial ${ }^{230} \mathrm{Th} /{ }^{232} \mathrm{Th}$ atomic ratio of $4.4 \pm 2.2 \times 10^{-6}$ (Taylor \& McLennan, 1985).

\section{SPELEO-GEOLOGIC SETTING}

The lower Jurassic carbonate platform limestone of the Calcare Massiccio Formation making up the core of the Valmontagnana-Frasassi blind thrust anticline in the Marche Apennines of central Italy, hosts the Frasassi karst complex (Fig. 3 A-B), which counts a dozen or so natural caves and caverns as registered in the regional cadaster. The largest interconnected cave system of the Frasassi complex is represented by the Grotta Grande del Vento (now a world-famous tourist show cave) and the Grotta del Fiume caves, both located in the south side of the Frasassi Gorge with a total development of about $25 \mathrm{~km}$ (Fig. 3A). The architecture of this cave system is characterized by seven subhorizontal levels (Bocchini \& Coltorti, 1978), which are connected by nearly vertical shafts. Of these hypogeal levels, the $3^{\text {rd }}$ and the $5^{\text {th }}$ are the best developed, while the $1^{\text {st }}$ level represents the local phreatic base level at about 200-205 m above sea level (asl). However, recent speleoscuba exploration of some hypogeal lakes revealed an astonishing maze of large caverns extending subhorizontally within the saturated phreatic zone down to depths of $\sim 30 \mathrm{~m}$ below base level (Jenn Macalady, pers. comm., summer 2016). It is in this subaqueous environment where dissolution of the limestone is presently occurring due to a localized sulfidic hypogenic karst process (e.g., Galdenzi et al., 1999, 2008; Forti et al., 2002; Macalady et al., 2006, 2008; Mariani et al., 2007). Hypogenesis occurs at Frasassi because sulfidic waters rich in dissolved $\mathrm{H}_{2} \mathrm{~S}$ upwell from the Triassic evaporitic anhydrites $\left(\mathrm{CaSO}_{4}\right)$ of the Burano Fm., into and through the overlying Calcare Massiccio limestone via a deeply-rooted fault and associated network of fractures and joints (Fig. 3B).

The multistory architecture of the cave system is the result of alternating erosion (thus incision) of the Sentino River flowing from west to the east at the bottom of the deeply incised Frasassi Gorge during interglacial warm and wet periods, and aggradation (valley fill) in cold and dry glacial periods, all this occurring during regional tectonic uplift (e.g., Cattuto, 1976; Galdenzi, 1990; Wegmann \& Pazzaglia, 2008: Montanari et al., 2019; and references therein). The dynamics of tectonic uplifting coupled with river incision implies that the upper levels of the cave system are the oldest (e.g., Taddeucci et al., 1992, 1994; Montanari et al., 2019) but it also means that, Frasassi being a hypogenic karst, the river will eventually cut the cave spaces that are currently forming several meters below its thalweg, which, in fact, represents the local base level. It is so that the craggy sides of the Frasassi Gorge are studded 


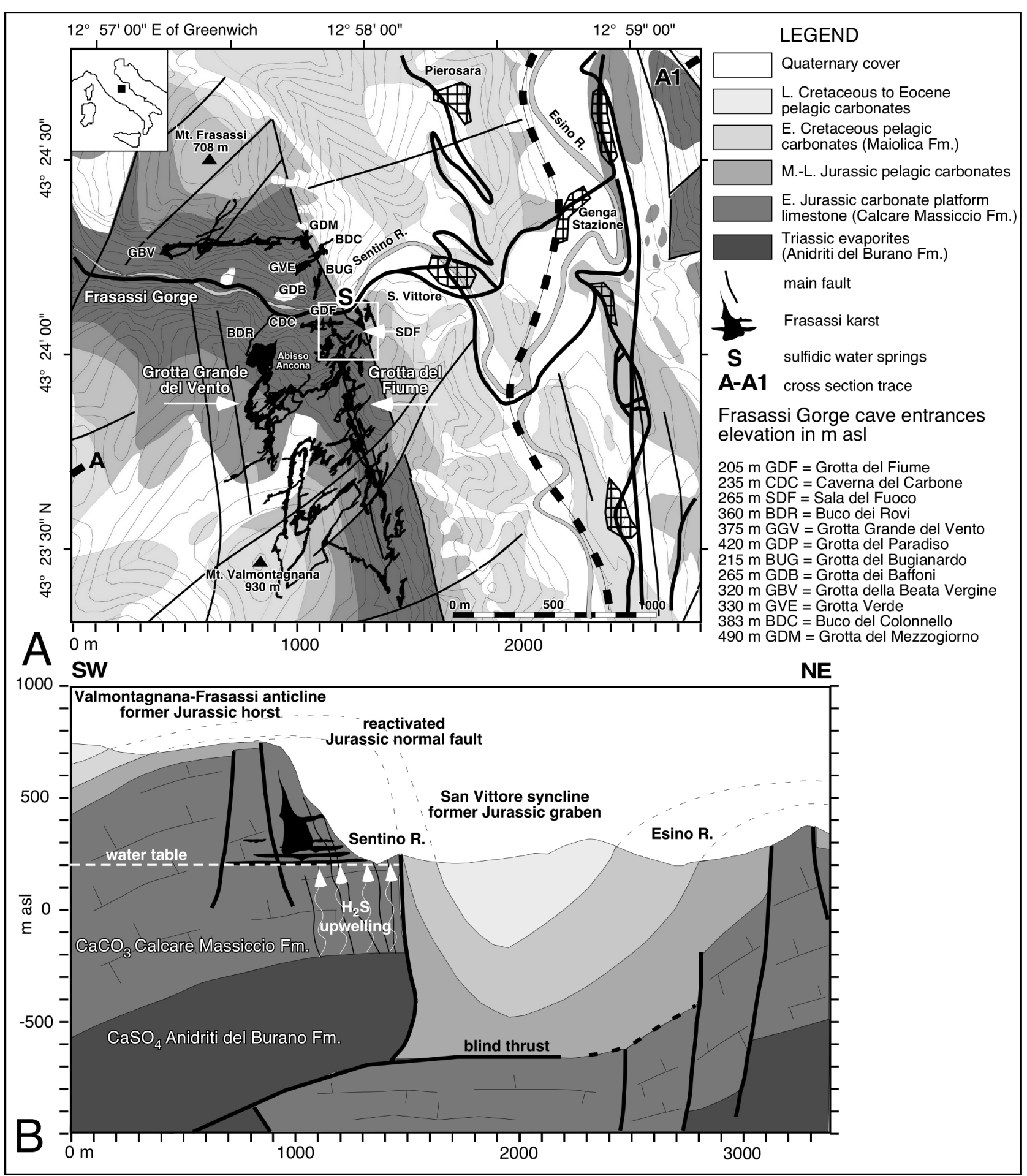

Fig. 3. Simplified geologic map (A) and cross section (B) of the Frasassi blind thrust-anticline (modified after Mariani et al., 2007), showing the location of the Frasassi hypogenic-karst cave complex incised by the Sentino River. The white-framed area of Grotta del Fiume in (A), with indicated the location of Sala del Fuoco (SDF), refers to Fig. 4B.

with cave apertures, caverns, and recesses (Fig. 3A) especially on the eastern end of the gorge. This is where the Frasassi cave complex develops on a NWSE general trend along a strongly fractured Calcare Massiccio limestone on the footwall of a reactivated Jurassic normal master fault (Fig. 3B), which, on the Valmontagnana side of the gorge, runs along a steep gully locally known as Fosso Riccio (Fig. 4A).

For a precise location of Sala del Fuoco and Galleria dello Stambecco with respect to the topography of the Fosso Riccio fault zone, we have joined our topographic survey to the original map of Grotta del Fiume of Bocchini \& Coltorti (1978), as shown in Fig. 4B. Sala del Fuoco turns out to be located at an elevation of $265 \mathrm{~m}$ asl (i.e., about $65 \mathrm{~m}$ above present base level), thus representing the well-developed $5^{\text {th }}$ level of the cave system, which was incised by the Sentino River probably in the late Middle Pleistocene around 200 ka (Cattuto, 1976; Taddeucci et al., 1992, 1994; Montanari et al., 2019, and references therein). In summary, the abundance of rupestrian caves found on the slopes and cliffs of the Frasassi Gorge is a geomorphic feature peculiar to this area in the context of the northern Apennine karst, and uniquely related to the coincidence of the localized sulfidic hypogenic karst process and the PleistoceneHolocene regional geotectonic activity (uplifting and incision). 

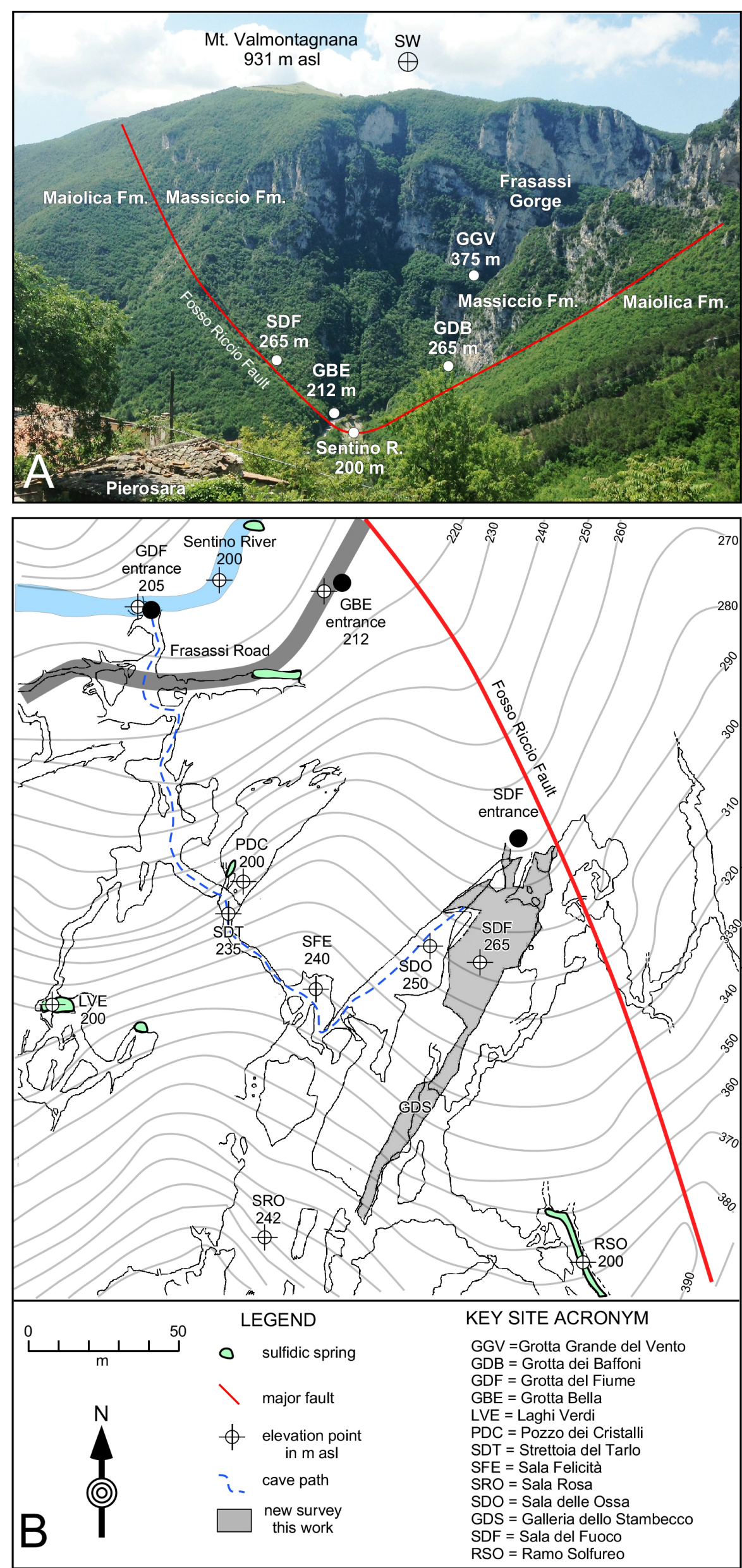

Fig. 4. A) Panoramic view of the eastern end of the Frasassi Gorge as seen from the hamlet of Pierosara (see Fig. 3A for location), with indicated cave entrances and their relative elevation in $\mathrm{m}$ asl, and the trace (red line) of the Fosso Riccio reactivated Jurassic normal fault (as shown in Fig. 3B).

\section{ENVIRONMENTAL AND GEOCHRONOLOGIC ASSESSMENTS}

\section{Hypogeal environment}

Through the years, in the Frasassi area archeologists have found evidence of human dwelling in a few caves, and radiocarbon dating indicated a frequentation period between 13,000 and 11,500 yr cal. BP (final Epigravettian; Pignocchi, 2015, 2018, and references therein). A number of archeological digs in the large Grotta della Beata Vergine Cave on the northwestern side of the Frasassi Gorge (see GBV in Fig. 3A) from the second half of the $19^{\text {th }}$ century through the first half of the $20^{\text {th }}$ century (Pignocchi \& Montanari, 2016, and references therein), yielded evidence of its utilization for funeral purposes from Early Bronze Age to medieval times, but no evidence ever emerged for preNeolithic frequentation other than the fortuitous find, by a casual visitor, of a Venus figurine of dubious Gravettian age (Coltorti et al., 2012; Pignocchi \& Montanari, 2016). Therefore, the fireplace in Sala del Fuoco in the Grotta del Fiume Cave preliminarily dated at about 16,300 yr cal. BP (Fig. 2), and the associated chert artifacts and ibex bones reported by Antonini (1986), represent the oldest evidence of Homo sapiens in a cave in this region of the northern Apennines.

In the Frasassi area, prehistoric finds were unearthed in relatively small and shallow cave shelters where daylight could diffuse directly in the dwelling (Broglio \& Lollini, 1982; Bartolomei \& Cattani, 2005). On the other hand, the vast cavern of Sala del Fuoco is located at such a distance from a probably narrow entrance that daylight could not reach. With the help of CB portable radios and ARVA avalanche transceiver, we have located within $5 \mathrm{~m}$ in the Fosso Riccio gully at about $265 \mathrm{~m}$ asl (Fig. 4A, B) the northeastern end of a narrow tunnel, which likely represented the access to Sala del Fuoco now obstructed by scree (Site 9B in Fig. 5A). Inside the cave, the vicinity of the surface was indicated by plant roots sticking out of the scree, and also by the presence of insects and a numerous population of salamander Speleomantes italicus. In the Moonmilk Room (Site 10 in Fig. 5A and $\mathrm{B})$, which contains the largest 


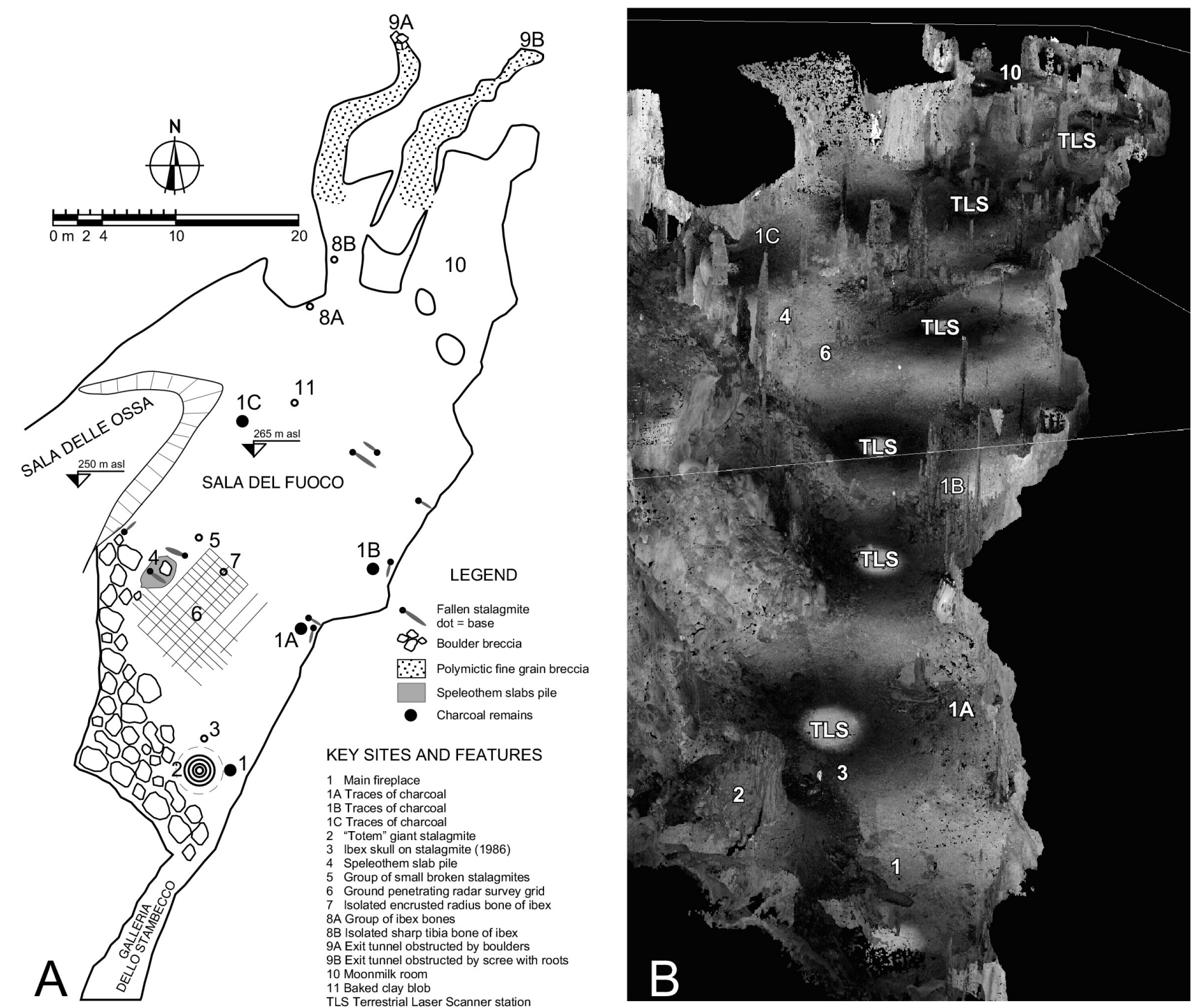

Fig. 5. A) Planimetric map of Sala del Fuoco with the locations of key sites and features described in the text; B) Three-dimensional view of Sala del Fuoco obtained from Terrestrial Laser Scanner survey of this cave space after combining six surveying stations (TLS).

deposit of fresh moonmilk (i.e., moist and still forming) ever found in any of the Frasassi caves, we have counted up to 64 clustered individuals of this troglobite amphibian at once. The scree itself was made up of a fine uncemented breccia (Fig. 6B) composed of angular clasts of multicolored limestones and cherts derived from various lower Cretaceous to Eocene pelagic carbonate formations, which at present are exposed at the top of Monte Valmontagnana (see Figs. 3A and 4A for location). Outside, the steep and densely forested Fosso Riccio gully did not offer any visible cave entrance anywhere around the precise point where we were getting the ARVA and CB radio signals loud and clear. Nevertheless, the soil of the gully turned out to be made up of a pedogenized fine polymictic breccia compositionally identical to the breccia that fills up the tunnel of Sala del Fuoco in Site 9B.

From the Moonmilk Room, going SW, one enters into the wide space of Sala del Fuoco, a flat bottom horizontal room some $50 \mathrm{~m}$ long, 20-30 m wide, and up to $10-15 \mathrm{~m}$ high, beautifully decorated with stalagmites of various colors (from white to oranges, beiges, and grays), and sizes (Figs. 5B and 6A). The ceiling and the eastern wall are mostly white in color due to a widespread coat of dry moonmilk. Stalactites are few, and are more numerous in the northern part of the room. Some of them have a dull appearance with a beige tinge, some others are whitish due to a coat of dry moonmilk. Overall, Sala del Fuoco appears quite dry at present with almost no active dripping. The floor is locally covered by limestone angular clasts of various sizes possibly resulting from stripping of the vault due to cryogenic processes and/or seismic activity, and often encrusted by speleothemic calcite. In the case shown in Fig. 6C (Site 7 in Fig. 5A), the millimetersthick speleothemic crust covers an intact ibex radius bone about $18 \mathrm{~cm}$ long, which yielded a collagen ${ }^{14} \mathrm{C}$ AMS age of 19,002-18,732 yr cal. BP (Table 1). The calcite crust (whole thickness, see insert in Fig. 6C) was dated to $10,130 \pm 480 \mathrm{ka}$ by U-Th (Table 2). ${ }^{14} \mathrm{C}$ AMS dating of the same speleothem sample yielded an age of 12,741-12,667 yr cal. BP (Table 1), 2,500 years older than the U-Th age, likely reflecting inputs of dead carbon from the bedrock (e.g., Valladas et al., 2017). It is worth noting that the floor speleothemic crust is dusted with carbonate particles resembling snowflakes (Fig. 6C), which probably fell from the moonmilk-encrusted walls and vaults of the cave (Fig. 6C). 

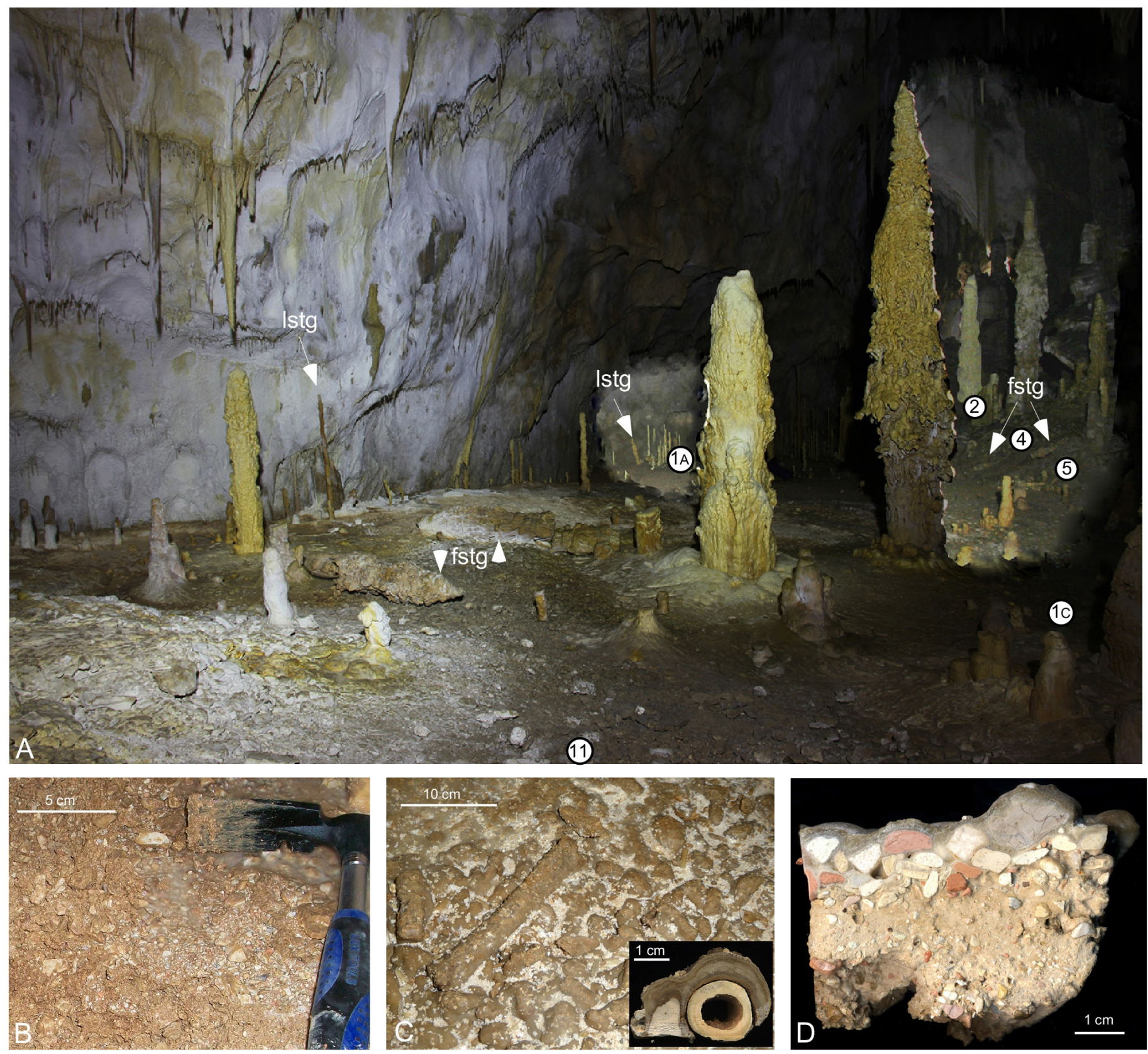

Fig. 6. A) Panoramic view of Sala del Fuoco indicating sites and features described in the text. Circled numbers refer to sites as in Fig. 5; fstg stands for fallen stalagmite, whereas Istg stands for leaning stalagmite; B) Close up view of the fine polymictic breccia obstructing the exit tunnel in Site 9B (see Fig. 5 A for location); C) Limestone breccia and ibex radius bone on the cave floor encrusted by speleothemic calcite (Site 7). The insert shows a section of the bone with the superficially enveloping speleothemic calcite crust; D) Cross section view of the cave floor made up of an alluvial deposit of moderately-to-well rounded sand grains and pebbles encrusted by speleothemic calcite.

Table 1. Radiocarbon ages for charcoal, bone, and speleothem samples from Sala del Fuoco in Grotta del Fiume (Frasassi, Italy) from AMS ${ }^{14} \mathrm{C}$ analysis.

\begin{tabular}{|l|c|c|c|c|c|c|}
\hline \multicolumn{1}{|c|}{ Lab code } & Sample name & Material & Measured & $\mathbf{\delta}^{\mathbf{1 3}} \mathbf{C} \%$ & Conventional & 2o calibration \\
\hline Beta Analytic & & & age (yr BP)* & & age (yr BP)* & calendar age (yr cal BP)* \\
\hline 545651 & SDF-1-COAL & charcoal & $13,440 \pm 40$ & -23.5 & $13,460 \pm 30$ & $16,372-16,015$ \\
\hline 545652 & SDF-1A-COAL & charcoal & $13,560 \pm 50$ & -28.8 & $13,500 \pm 50$ & $16,479-16,058$ \\
\hline 545653 & SDF-1B-COAL & charcoal & $13,450 \pm 40$ & -26.9 & $13,420 \pm 40$ & $16,310-15,970$ \\
\hline 545654 & SDF-1C-COAL & charcoal & $13,830 \pm 40$ & -23.3 & $13,740 \pm 40$ & $16,999-16,558$ \\
\hline 465542 & SDF-MANDIBULA & mandible bone & $13,650 \pm 40$ & -19.5 & $13,740 \pm 40$ & $16,835-16,362$ \\
\hline 461958 & SDF-MAXBONE & radius bone & $15,530 \pm 60$ & -19.3 & $15,620 \pm 60$ & $19,002-18,732$ \\
\hline 461960 & SDF-MAXCRUST & speleothem calcite & $10,440 \pm 30$ & -4.6 & $10,770 \pm 30$ & $12,741-12,667$ \\
\hline
\end{tabular}

Accelerator mass spectrometry (AMS) radiocarbon dating was performed at Beta Analytic Inc. (Florida) following methods and techniques in http://www.radiocarbon.com/accelerator-mass-spectrometry.htm.

"Dates are reported as radiocarbon years before present, where "present" = AD 1950. 


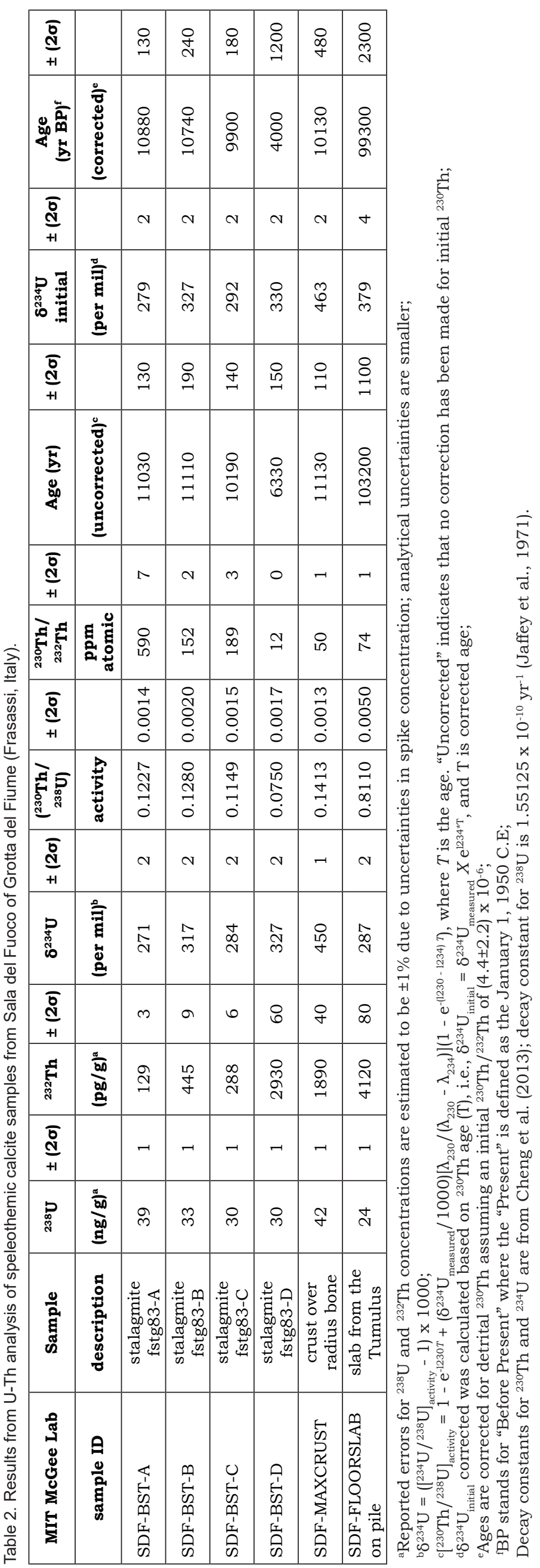


In other places throughout the cavern, the floor calcite crust covers an alluvial slack water deposit made up of moderately-to-well rounded sand grains and pebbles (Fig. 6D) of varied lithology, which represent the formations of the Jurassic to Miocene Umbria-Marche sedimentary succession, practically the same lithologic composition of the sediment making up Pleistocene fluvial terraces as well as the present-day Sentino river bed. As for the stalagmites, they range from a few $\mathrm{cm}$ to a few $\mathrm{m}$ in height. The tallest of all, with an estimated height of 5-6 m and a diameter at the base of about $1 \mathrm{~m}$, is the one located at the southern end of the room next to the fireplace (Site 2 in Fig. 5A, B and visible in the far distance of panoramic view in Fig. 6A), and here christened the "Totem". Interestingly, half a dozen or so relatively large broken stalagmites are laying down on the floor or leaning against the eastern side wall of the cave, with a common NW-SE axial trend (Figs. 5A and 6A). This suggests that these fallen stalagmites were knocked down by a violent seismic shear wave, which propagated from an epicenter that was located either to the SE or to the NW of Sala del Fuoco.

In order to envision how the environment of Sala del Fuoco may have looked like some 16,300 years ago, it would be necessary to determine the age of the speleothems, and assess which ones were already present there when this hypogeal room was visited by humans. Intuitively, small, slim, fresh looking stalagmites are younger than larger and taller ones, but this could well be a sidetracking intuition. A $5 \mathrm{~cm}$ stalagmite growing on a chert artifact found by Forestalp (1987) in Sala del Fuoco turned out to be $1,500 \pm 400 \mathrm{yr}$ old after U-Th dating by Taddeucci et al. (1992, 1994). The oldest U-Th date of $199 \pm 21 \mathrm{ka}$ ever obtained from a speleothem from the $5^{\text {th }}$ level of the Grotta del Fiume Cave (i.e., Sala del Limone, at about $265 \mathrm{~m}$ asl) was from the base of a 30-cm-tall stalagmite (Taddeucci et al., 1992). With the intention of contributing to the reconstruction of the speleothemic history of this cave, we have U-Th dated a 83-cm-long broken piece of a stalagmite (sample SDF-fstg83; Fig. 7A), probably taller than $130 \mathrm{~cm}$ in origin before it was knocked down from its $50 \mathrm{~cm}$ stump. This fallen stalagmite now rests head-down with a NW-SE axial trend over an intriguing pile of broken speleothemic slabs (Fig. 7A; for location, see Site 4 in Figs. 5A and $6 A)$. The facing-up side of the stalagmite is covered by a thin layer of finely laminated gray speleothem (Fig. 7B), which was deposited from localized dripping after it fell. Also the piled up slabs are locally encrusted by the same gray speleothemic cover (Fig. 7C). An age of about $10.8 \mathrm{ka}$ for the oldest part of the $21 \mathrm{~cm}$ long stalagmite piece we sampled, and an age of about $9.9 \mathrm{ka}$ for the youngest part of it (Table 2; Fig. 7B), suggest a mean growth rate of $0.02 \mathrm{~mm} \mathrm{yr}^{-1}$. Considering that the basal stump still in place is about $50 \mathrm{~cm}$ tall, this suggests that the stalagmite started to grow way before the end of the last glacial. On the other hand, the gray laminated speleothem covering the facing up side of the fallen stalagmite yielded a U-Th age of 4,000 $\pm 1,200$ years (Table 2; Fig. 7B), which suggests that the stalagmite fell down over the slab pile not later than 4-5 thousand years ago. Of course direct dating of the base and tip of the whole stalagmite will eventually give a more accurate geochronology of its growth history, and a better-constrained date of its fall. On the other hand, a piled up speleothem slab yielded an age of $99.3 \pm 2.3 \mathrm{ka}$ (Table 2; Fig. 7C), suggesting that speleothemic concretion was going on already tens of thousand years before Sala del
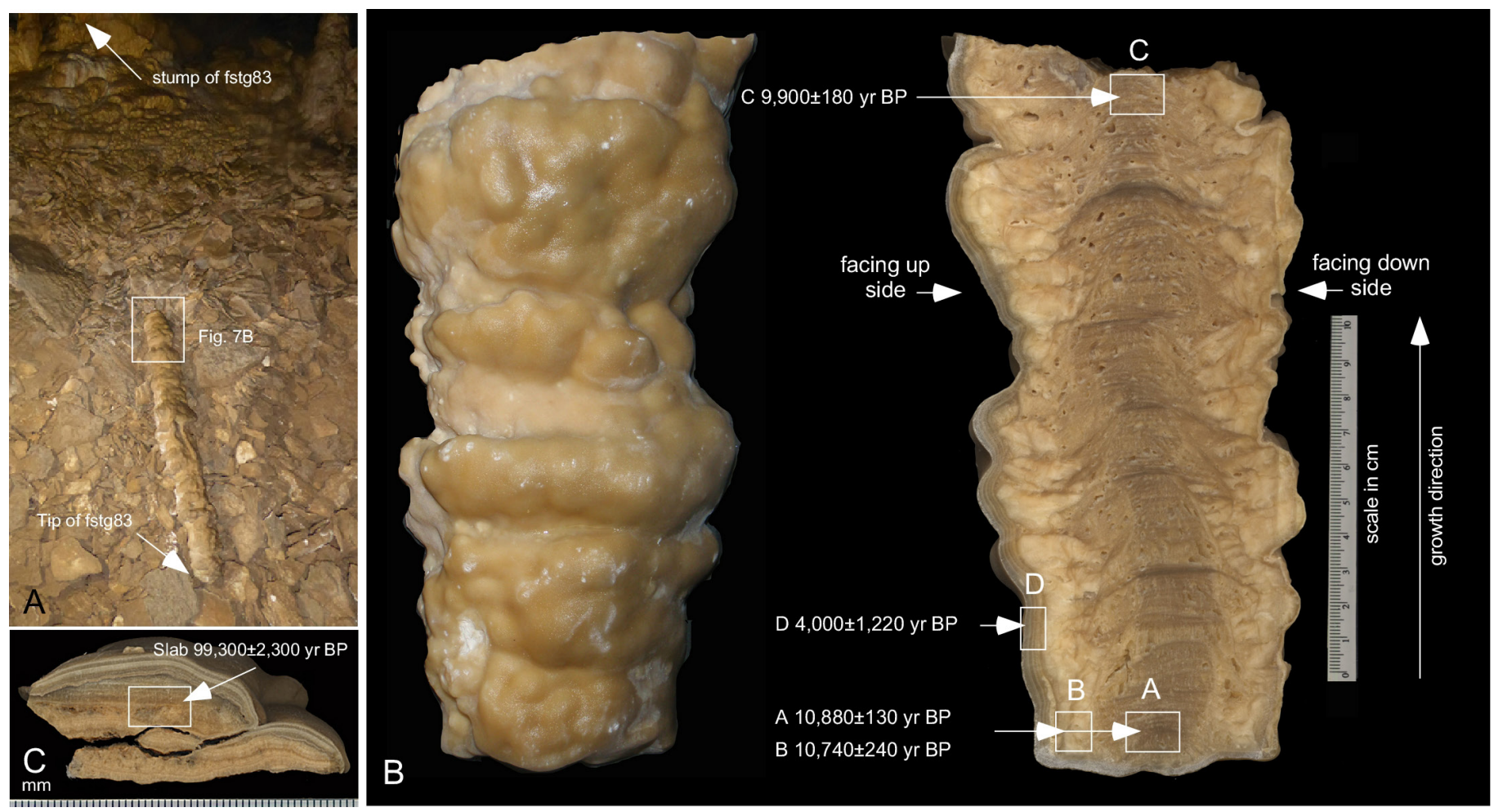

Fig. 7. A) 83-cm-long piece of a stalagmite (sample SDO-fstg83) snapped from its stump and fallen over a pile of speleothemic calcite slabs; B) Lower part of sample fstg83 (natural external and polished section views) with U-Th dates from four spot subsamples (A, B, C, and D);

C) Polished surface of a calcite slab from the slab deposit showing the part dated with U-Th at $\sim 100 \mathrm{ka}$. 
Fuoco was visited by humans. Nevertheless, these few educated observations corroborated by radioisotopic geochronology induce us to envision a Sala del Fuoco around 16 thousand years ago much more bare of speleothems than it is today. The 5-m-tall Totem was probably one of the few conspicuous speleothems decorating this hypogeal environment, and likely the most imposing.

\section{Quest for fire}

The remains of a fireplace at the foot of the Totem giant stalagmite (Fig. 8A; Site 1 in Fig. 5), consist of small charcoal particles distributed on the floor in a roughly circular area about $1 \mathrm{~m}$ in diameter (Fig 8B). In this site, the floor is made up of uncemented limestone breccia. When one of us (S. M.) first visited Sala del Fuoco in 2002, he found the fireplace marked by limestone and speleothem boulders arranged in a circle around the burnt ground. The rocks were placed there probably by earlier cavers with the considerate intention of protecting the site from possibly passingby inattentive spelunkers. Among the burnt limestone breccia (including a few broken pieces of stalactites), we did not notice any bone remains but only black carbon particles. The flowstone "bib", which festoons all around the base of the Totem, is clearly blackened in the sector adjacent to the fireplace (Fig. 8B), whereas everywhere else it is whitish in color. The Totem itself exhibits a pristine white color. On the other hand, the cave wall next to the fireplace is spotted with a brownish stain up to several meters above the floor, which contrasts with the otherwise white color of the dry moonmilk that coats the vaults of the cavern. This may be the result of the smoke produced by the fireplace. A more convincing evidence for smoking of the environment around the fireplace is given by a micron-thick veneer of actual black soot, which covers a clay deposit (i.e., a clay-rich slack water sediment) found along the Galleria dello Stambecco (Fig. 8A, and Fig. 5A for location). This long tunnel puts Sala del Fuoco, and in particular the fireplace area, in direct communication with the vast spaces of the inner parts of the Grotta del Fiume cave, from here immediately down to the Sala delle Ossa room (Fig. 5A for location). This may have provided some ventilation for the smoke produced by this primitive bonfire, which would have directed the smoke towards the inner part of the cave rather than in the ambience of Sala del Fuoco. In any case, a new small sample of charcoal was collected in one of our last expeditions in 2019 with the intention of replicating, in a different lab, the original ${ }^{14} \mathrm{C}$ AMS date of $16,646-16,046 \mathrm{yr}$ cal. BP (Fig. 2). In fact, the new charcoal sample yielded an age of 16,372-16,015 yr cal. BP (Table 1), slightly more precise but indistinguishable, at a $95 \%$ confidence level, from the original date.

The fireplace described above is not the only evidence of fire lighting in Sala del Fuoco. We have identified three other charcoal deposits in this cave room, two small ones next to the eastern wall of the cave (Sites $1 \mathrm{~A}$ and $1 \mathrm{~B}$ in Fig. 5A), and a larger third one on the central-western side of the room next to the edge of the 15-m-deep vertical shaft that drops down to Sala delle Ossa (Site 1C in Fig. 5A).
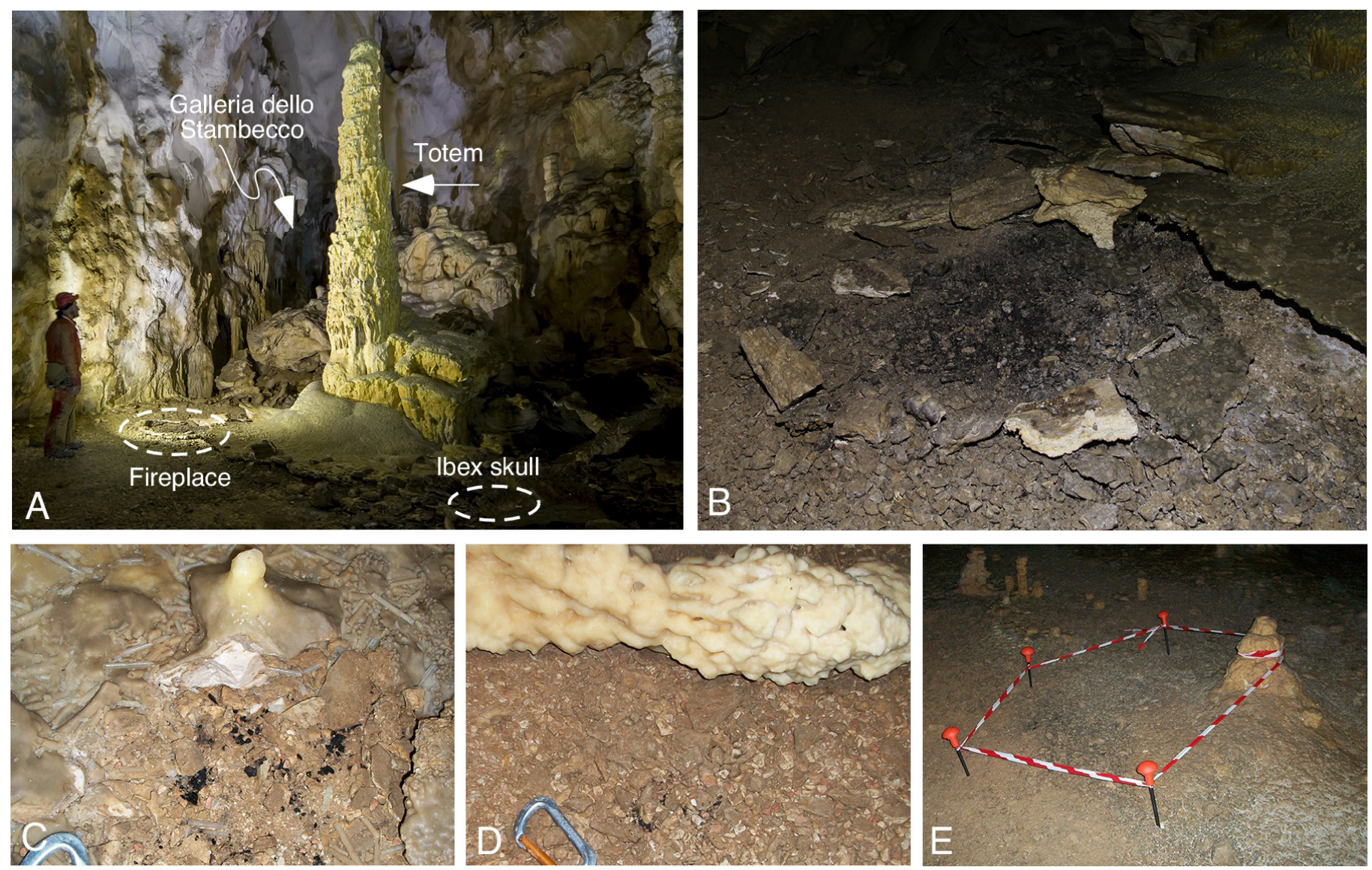

Fig. 8. A) Panoramic view of the area around the Totem giant stalagmite with indicated the main fireplace and the site where the ibex skull was found by Antonini (1986) set on the tip of a short stalagmite; Close up view of (B) the main fire place on Site 1 in Fig. 5; C) charcoal particles on Site $1 A ; D$ ) traces of charcoal on Site 1B; E) traces of a fire place on Site 1C. 
Site 1A consists of a sprinkle of charcoal particles resting on top of a fine polymictic alluvial gravel similar to the one shown in Fig. 6D. It must be pointed out, however, that this charcoal deposit may have been spread over a larger area around the presently exposed find, which is now covered by a speleothemic crust and a group of small stalagmites (Fig. 8C). A sample of this charcoal yielded an age of 16,479 $16,058 \mathrm{yr}$ cal. BP, thus indistinguishable from the age of the charcoal from the main fireplace (Table 1).

Site $1 \mathrm{~B}$ is located about $5 \mathrm{~m}$ from Site $1 \mathrm{~A}$ (Fig. 5A for location). As in the previous case, charcoal particles lay on polymictic alluvial gravel well exposed over a wide surface (Fig. 8D). Yet it does not consist of a single concentrated spot but sporadic charcoal particles are found aligned on a 5-6 $\mathrm{m}$ long track directed toward the center of the room. This distribution suggests that these charcoal finds may not represent a fireplace but possibly the sites where small spotlights or torches were lit to illuminate the room. A sample of the charcoal collected from Site 1B yielded an age of 16,310-15,970 yr cal. BP, once again indistinguishable from the age of the charcoal from the main fireplace (Table 1).

On Site 1C, charcoal specks were found sparse over a half square meter area where the floor is made up of cemented limestone breccia dusted with moonmilk particles (Fig. 8E), a situation similar to the one seen on Site 7 shown in Figure 6E. However, close observation revealed that the limestone clasts around the exposed (visible) charcoal particles are darker than those making up the floor of the surrounding area, suggesting that they have been baked by fire. It is worth mentioning that at a short distance from this smaller fireplace, we found a blob of what looked like red terracotta. Examination under the microscope revealed that this material was indeed a blob of clay, which had been baked in an open fire. As a simple test, we produced a very similar material by baking in a house fireplace a blob of a clay sample collected from the aforementioned Galleria dello Stambecco. These observations lead to the hypothesis that this was the site of another fireplace similar to the one found at the foot of the Totem at the very end of the room but this time placed at the edge of a gloomy chasm, i.e., the northeastern 15-m-tall vertical wall of Sala delle Ossa. A sample of the charcoal collected from this site yielded a ${ }^{14} \mathrm{C}$ AMS age of 16,999-16,558 yr cal. BP (Table 1). This age, equivalent to $\sim 16.8 \pm 0.2 \mathrm{ka}$, is several hundred years older than a mean age of $\sim 16.3$ $\pm 0.2 \mathrm{ka}$ obtained from the other charcoal samples.

\section{The steinbock ossuary}

In August 1971, a team of cavers from Gruppo Speleologico Città di Jesi passed through a bottleneck passage in the Grotta del Fiume at the top of a shaft known as Pozzo dei Cristalli (see PDC in Fig. 4B for location), and named it Strettoia del Tarlo (Bottleneck of the Woodworm; see SDT in Fig. 4B for location). Past the bottleneck and at the end of a narrow passage, the cavers discovered a new huge development of Grotta del Fiume consisting in a maze of chambers, tunnels, and shafts penetrating into the mountain for more than a kilometer. One of the first large chambers they explored was christened Sala delle Ossa (Room of the Bones; see SDO in Fig. 4B for location) owing to the fact that they found there a number of animal bones and a well-preserved skull of ibex. This material was eventually delivered to the Institute of Geology of the University of Ferrara. This discovery was reported by Coltorti \& Sala (1978) who recognized that the bones found in Sala delle Ossa, which included a few fragments of ribs and vertebrae, some finger bones, the epiphysis of a tibia, and the skull of a senile female specimen (probably 12 years in age or older), they all belonged to an adult ibex. They also hypothesized that the animal fell in a sinkhole from outside the cave down onto the floor of that large, 25-m-high room. Unfortunately, the collection from Sala delle Ossa was not properly registered nor archived at the Institute of Geology of the University of Ferrara, and consequently the bone specimens described by Coltorti \& Sala (1978) cannot be traced back today. On the other hand, we can say with hindsight that there are no sinkhole openings on the ceiling of Sala delle Ossa but only a $\sim 15 \mathrm{~m}$ high vertical wall, which climbs up to the overhanging western edge of Sala del Fuoco (see Fig. 5A for location), where, in fact, more ibex bones were discovered by the cavers of the GSM of Ancona 15 years later (Antonini, 1986).

Apart from the isolated radius we found encrusted on the floor of Site 7 (Fig. 6E), and the ibex skull found on the tip of a stalactite, of which the sole evidence of its existence is the photograph taken by an unknown caver in 1986 (Fig. 1) as published in Parco Naturale Regionale della Rossa e di Frasassi (2000), and also the "numerous bones" originally reported by Antonini (1986) and Forestalp (1987), only a handful of mostly broken bones were found by us in Sala del Fuoco, beneath the cave wall in Site 8A (see Fig. 5A for location). They were actually distributed in two separate groups about $40 \mathrm{~cm}$ from each other (Fig. 9A). In addition to these, a single piece of a long bone was found on Site $8 B$, just a few meters from Site 8A in Figure 5A (see bone n. 17 in Fig. 9B). At first glance, it appeared that the bones arranged in that way in Site 8A were not representing the leftovers of a predator's meal, like that of a fox, a wolf, or a big cat, which, unless they are clustered around a scavenged carcass, are usually found spread over a much larger area. The bone fragments were of different kinds (long limb bones, short bones such as vertebrae, flat bones such as ribs) ranging in length from a few to several $\mathrm{cm}$. After having taken high-resolution photographs of this site, we collected all the bone fragments we could find (about 70 pieces in total; Fig. 9B and C), took close up pictures of each specimen, and eventually we dutifully delivered the whole collection to the Archeological Superintendence in Ancona on December 12, 2017.

One of the most conspicuous specimens we collected is the central portion of a left mandible of a bovid (i.e., compatible with an ibex) with a dp4 (fourth deciduous premolar) and $\mathrm{m} 1$ (first molar) still in place in their alveola. The presence of a milk tooth and the almost unworn first molar, indicate that the animal was not 

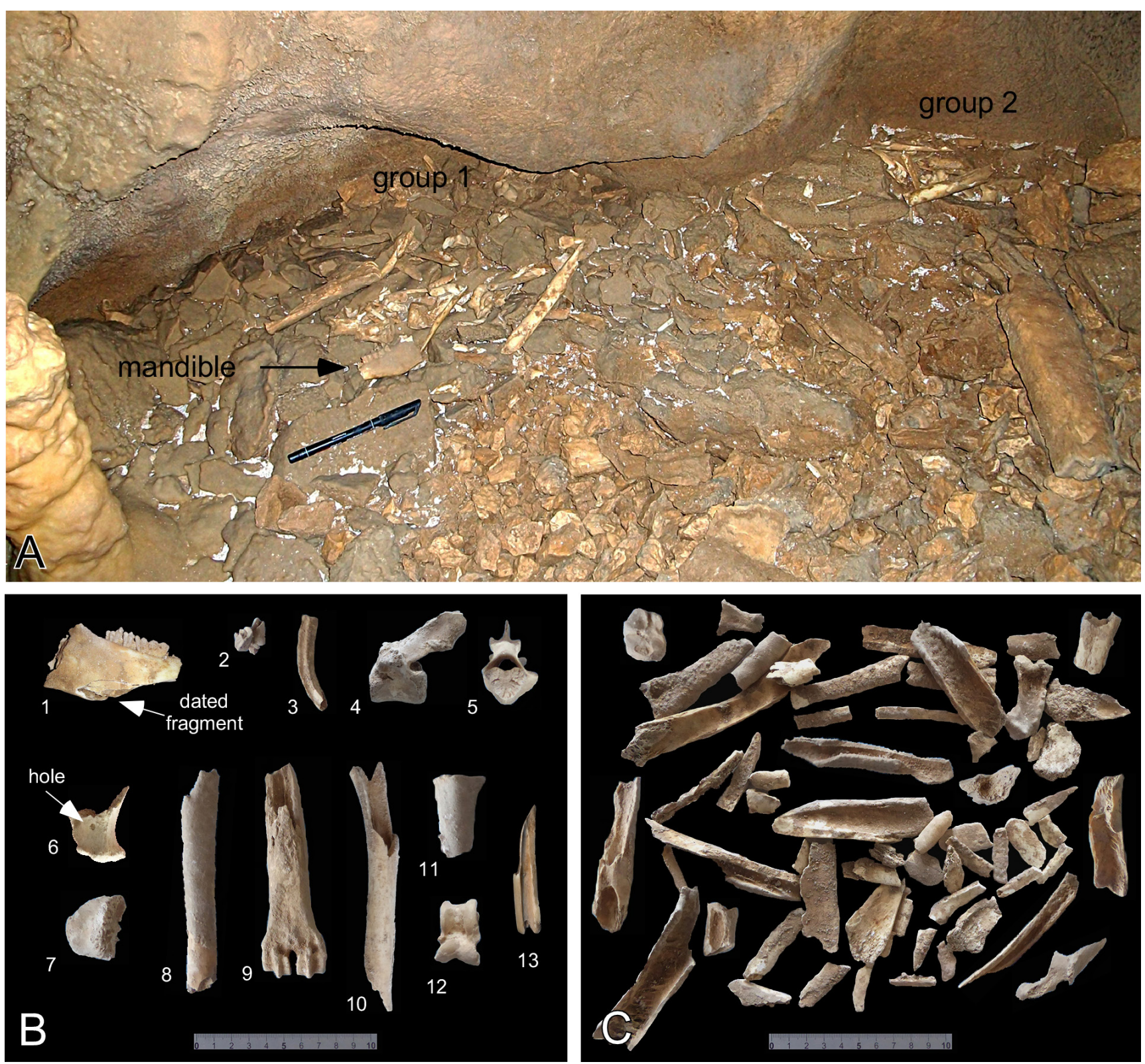

Fig. 9. A) Close up view of the two groups of bones as we found them in Site 8A in Fig. 5; B) Selection of diagnostic ibex bones (1 to 12) from Site 8A, and bone n. 13 from Site 8B: 1) fragment of left mandible with dp4 and $\mathrm{m} 1$ (lingual view); 2) fragment of lower molar, probably $\mathrm{m} 2 ; 3$ ) root of incisor tooth; 4) and 5) thoracic vertebrae; 6) fragment of scapula showing a possible tooth mark; 7) unfused olecranic process of ulna; 8) diaphysis of radius; 9) right metacarpal; 10) diaphysis of ulna; 11) proximal end of metatarsal; 12) right astragalus; 13) diaphysis of tibial; C) All non-diagnostic ibex bone fragments collected from Site 8A.

older than one year. Collagen from a small fragment of the lower part of the jaw yielded a ${ }^{14} \mathrm{C}$ AMS age of $16,835-16,362$ yr cal. BP, thus indistinguishable, at a $95 \%$ confidence level, from the age of the main fireplace (Table 1). All the other bones do not show traces of butchery carving, nor of masticatory snapping, except for a $3 \mathrm{~mm}$ circular hole in bone $\mathrm{n}$. 6 (indicated in Fig. 9B), which could have been produced by a canine bite from a carnivore. Almost all long bones are fractured longitudinally (Fig. 9C), a fact that is not agreeable with the chewing action of an animal but is more compatible with the crushing of the bone with a stone, a common practice by primitive hunters trying to suck out the palatable bone marrow.

All more or less diagnostic bones found in Site 8A may represent a single, medium-size juvenile bovid, probably a one-year-old ibex. This assessment is suggested by the absence of double bones (for instance two right humeri), the size and tenuity of long bones, some bones with not fused epiphysis, and a milk tooth still in place in its mandibular alveolus. For sure, these bones are not compatible with the skull of an adult male ibex discovered near the main fireplace by Antonini (1986) as pictured in Figure 1, nor with the skull of an old female ibex found in Sala delle Ossa by Coltorti \& Sala (1978). Nevertheless, our taphonomic observations lead to the doubt that the two groups of bones, as we found them in site 8A, rested in situ since the time they were consumed probably by prehistoric troglodytes. It is difficult to envision that Epigravettian hunters after eating one or more ibex animals around a fireplace in this cozy hypogeal environment, would have eventually disposed of the bones in that corner of the cave. It is more likely that the bones were originally scattered all over the place and then, in recent times, spelunkers inspecting the cave floor in search of collectable finds, picked up these bones, even centimeter-sized fragments, and just tossed them in that corner because they were of scarce interest (i.e., in collector's jargon, they were 
not keepers). The same cannot be said for bone n. 17 (Fig. 9B), which was found isolated beneath the western wall of the tunnel in Site 8B (see Fig. 5A for location). This bone fragment is the diaphysis of a bovid tibia, with a surface markedly more weathered than the bones in Site 8A, suggesting that it does not belong to the same juvenile animal. Moreover, this bone has been longitudinally fractured just as almost all long bones of Site 8A but a closer inspection suggests that the fracture was subsequently retouched to create a sharp curved edge terminating in a point. Similar bone artifacts were found, for example, in the late Epigravettian (13,000-13,500 yr cal. BP) site of Riparo Dalmeri (Trentino, southern Alps), which were typologically classified as "point with distal finishing PFD3” by Bazzanella (2005).

\section{Chert artifacts}

The chert artifacts found in Sala del Fuoco (Fig. 10) and currently preserved in the archive of the Archeological Superintendence of Marche in Ancona (Forestalp, 1987), consist of three simple-knapping, unretouched blades, and a well-crafted point on blade support with deep simple retouching partially covering the apex at the left distal end of the dorsal side. This point can be classified as type P2 (deep point) tending to type F3 (flat face point) according to the systematic classification of Laplace (1964). These artifacts are all made up of a high-quality, isotropic red radiolarian chert found in place as nodules and layers in the pink pelagic limestones of the Eocene R4 member of the Scaglia Rossa Formation in the Umbria-Marche Apennines (Montanari et al., 1989), but also as pebbles and larger isolated cobbles in calcareous gravels making up Quaternary fluvial terraces throughout this region.

These four chert artifacts represent per se a nondiagnostic, very small sample of Upper Paleolithic lithic industry. Abundant and diversified chert artifacts were found in a few archeological digs of Early Epigravettian workshops in a restricted area of the eastern foothills of the central Marche ridge, namely at Ponte di Pietra near Arcevia, some $10 \mathrm{~km} \mathrm{NW}$ of Frasassi, Fosso Mergaoni near Serra San Quirico (21,400 yr cal. BP), about $8 \mathrm{~km} \mathrm{NE}$ of Frasassi, Baracche $(18,200$ yr cal. BP), and Madonna dell'Ospedale near Cingoli, some $20 \mathrm{~km}$ E of Frasassi (e.g., Broglio et al., 2005; Silvestrini et al., 2008, and references therein). These few archeological sites suggest brief periods of occupation by probably nomadic hunter-gatherers communities, which were finalized to the production and export of lithic artifacts on blade support (Silvestrini \& Peresani 2007). Therefore, we can assess that the chert artifacts found in Sala del Fuoco were crafted in the period between 17,000 and 16,000 years BP, as radiocarbon dating of charcoal and ibex bones found associated with them would suggest, and that they testify a rare Epigravettian lithic industry in this area of the northeastern Apennines.

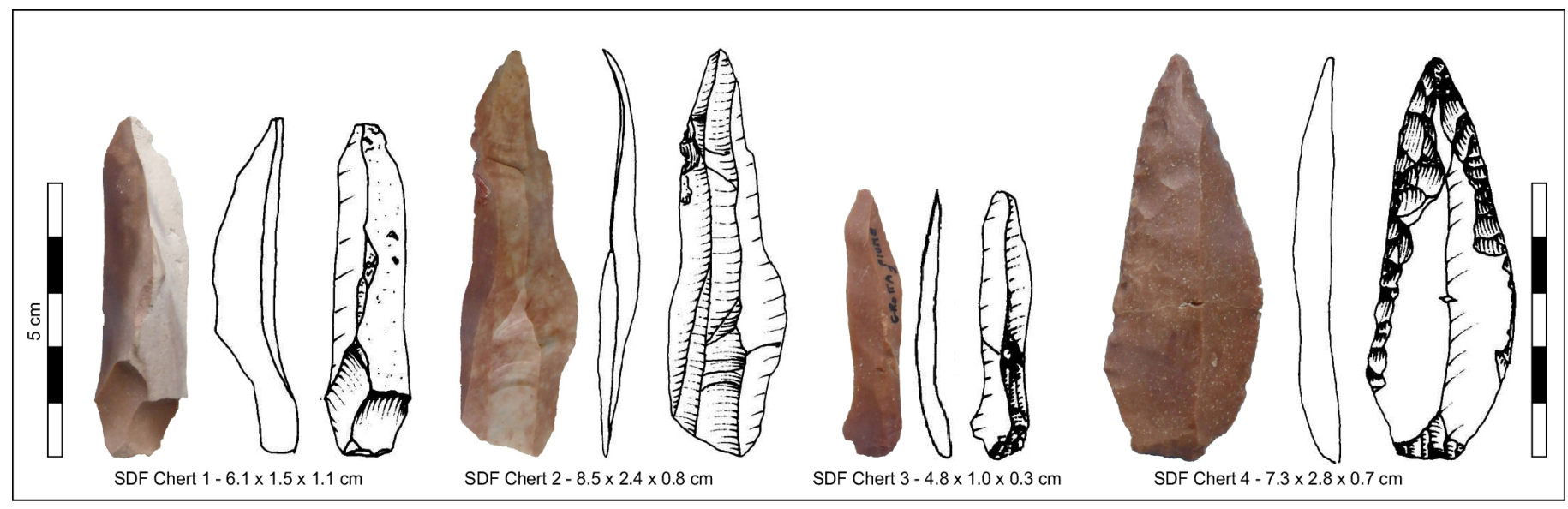

Fig. 10. The four chert artifacts found in Sala del Fuoco by Forestalp (1986) and deposited at the Archeological Superintendence in Ancona. The three specimens on the left are simple blades whereas the specimen on the right is a type P2 deep point with a good degree of retouching.

\section{The slab pile}

The southwestern side of Sala del Fuoco is bound by boulder breccia deposits, which testify to a history of collapses of the vaults probably caused by strong earthquakes (Fig. 5A). These boulder breccias are a common feature in all large rooms of the Grotta del Fiume-Grotta Grande del Vento cave complex (Bocchini \& Coltorti, 1990), including Sala delle Ossa, which is adjacent to Sala del Fuoco. However, in a small area on the northern end of Sala del Fuoco's boulder breccia (Site 4 in Fig. 5A; see panoramic view in Fig. 11), we noticed an unusual deposit of handsize, 1 to $3 \mathrm{~cm}$-thick slabs made up of speleothemic calcite, covering an area of about $1.5 \times 1.5 \mathrm{~m}$. The slabs do not exhibit the kind of texture, such as growth laminations perpendicular to the flat surface, which is typical of stalactitic curtains, but rather thin laminations parallel to surface as they can be found in stalagmites, flowstones, or speleothemic floor crusts (e.g., Fig. 7C). Therefore, we inferred that the piled-up slabs were derived from the floor and not from the ceiling of the cave. In fact, the cave floor immediately in front of the slab mound, which is made up of uncemented alluvial and/or fine breccia sediment, is flat and free of speleothemic crust (Fig. 11). In short, we speculated that an original thin speleothemic floor crust has been broken up into pieces, which were then tossed on the side to form a mound, an action this that can be performed only by humans.

The question now arises why presumably Paleolithic ibex hunters, would have engaged in the labor of removing a hard calcite crust from the floor of this 


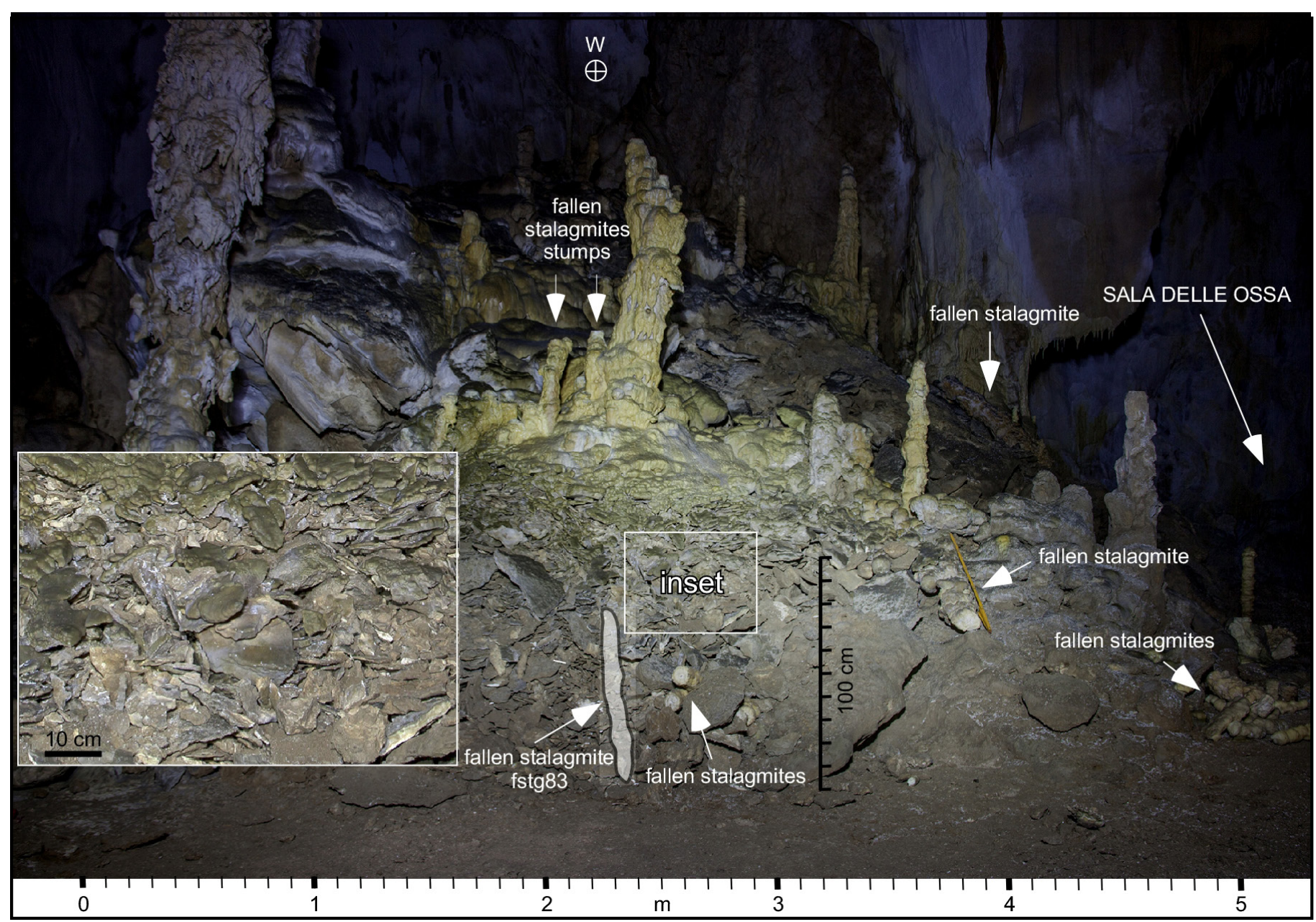

Fig. 11. Panoramic view of the slab pile. The insert shows the arrangement of piled-up speleothemic calcite slabs making up this deposit.

deep cave. A first hypothesis coming to our mind was that these people wanted to dig a ditch in the loose sediment sealed under the hard calcitic crust, perhaps to create a grave to bury a corpse. In order to test this hypothesis in a non-destructive manner, we carried out a ground penetrating radar (GPR) survey over the flat floor immediately in front of the slab mound (see Site 6 in Fig. 5 for location) covering an area of about $8 \times 6 \mathrm{~m}$ (Fig. 12A). A similar GPR survey was performed by one of us (M. M.) in an abandoned medieval Jewish cemetery in Ancona, now a city park known as Campo degli Ebrei (Mainiero, 2003). The job, which was commissioned by the City of Ancona on behalf of the city's Jewish community for the reclamation of this historical site and the eventual transposition of human remains, consisted in utilizing the sensitive GPR instrument to localize underground anomalies in the reflected radar signals, which could be interpreted as reworked volumes of sediment, coffins, or skeletons.

While the GPR investigation in the Jewish cemetery was successfully accomplished, our search for a grave or a buried skeleton in Sala del Fuoco, which would have produced anomalies such as hyperbolic reflections in the size range of 70 to $150 \mathrm{~cm}$, did not give positive results. Nevertheless, the survey gave some interesting information about the structure and composition of the alluvial deposit making up the floor of Sala del Fuoco down to a subsurface depth of $3 \mathrm{~m}$. The longitudinal sections parallel to the front of the slab mound (Fig. 12B to E) reveal a fairly homogeneous sedimentary body but with a gradual decrease with depth of the strength of the reflected signals. This is probably due to variations in the composition/texture of the sediment (sand vs. clay), and/or variations in the water content with depth. In lines L01 and L02 (Fig. 12B and C, respectively), an irregular body some $5 \mathrm{~m}$ wide with strong reflected signals appears at a depth of about $2 \mathrm{~m}$. We interpret this anomaly as the buried toe of the boulder breccia onto which the slab mound rests, which slopes up to the $\mathrm{W}$ for a meter or so above ground level (Fig. 11). At a distance of about $3 \mathrm{~m}$ from the edge of the slab pile, this anomaly is no longer present. Similar signals are present at about the same depth in the transverse lines T01 to T09 (Fig. 12G to K), which could also be interpreted as representing the toe of the same buried boulder breccia. Finally, all the transverse lines except for T01 (i.e., T02 to T13 in Fig. 12F to M) reveal an inclined signal starting at a depth of about $1.5 \mathrm{~m}$, at a distance of $3 \mathrm{~m}$ from the edge of the slab pile, and with a rake toward NW, which may represent an angular unconformity within the alluvial deposit. A similar anomaly is also present in longitudinal line L04 (Fig. 12D).

The negative result of our GPR survey, which was aimed at identifying a grave or a buried skeleton, did not invalidate the original inference that the floor crust has been broken up into pieces by human hands, and that the broken slabs were then stacked up on the side to form a mound. As an alternative explanation, we are herein proposing the hypothesis 
that the slab pile may represent a burial structure, i.e., a sort of earthen mound (e.g., Arias, 2009). In this case, a corpse would have been laid down in a recess of the boulder breccia and then covered up with the slabs stripped out of the speleothemic floor crust.
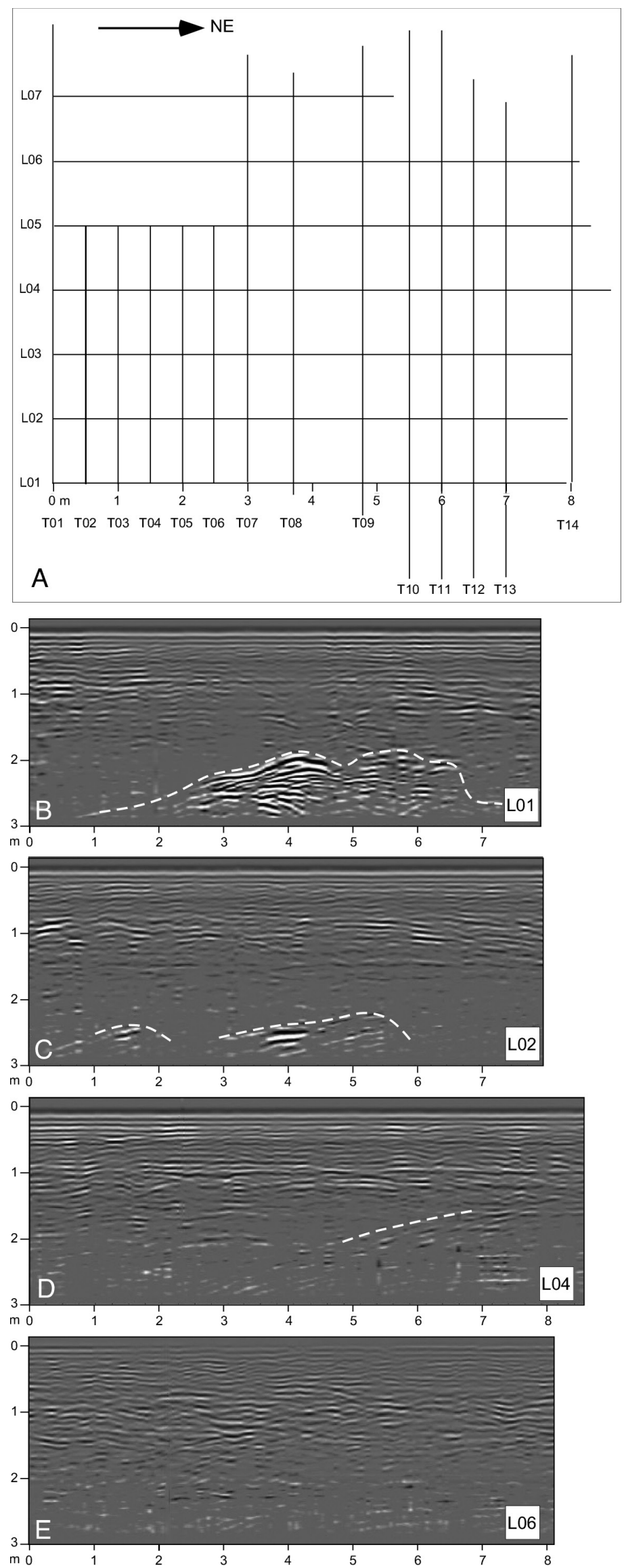

Needless to say, this hypothesis can only be tested by carrying out a proper archeological dig, which implies the removal of the slabs from the mound, an operation that would require the permission and supervision of the regional Archeological Superintendence.
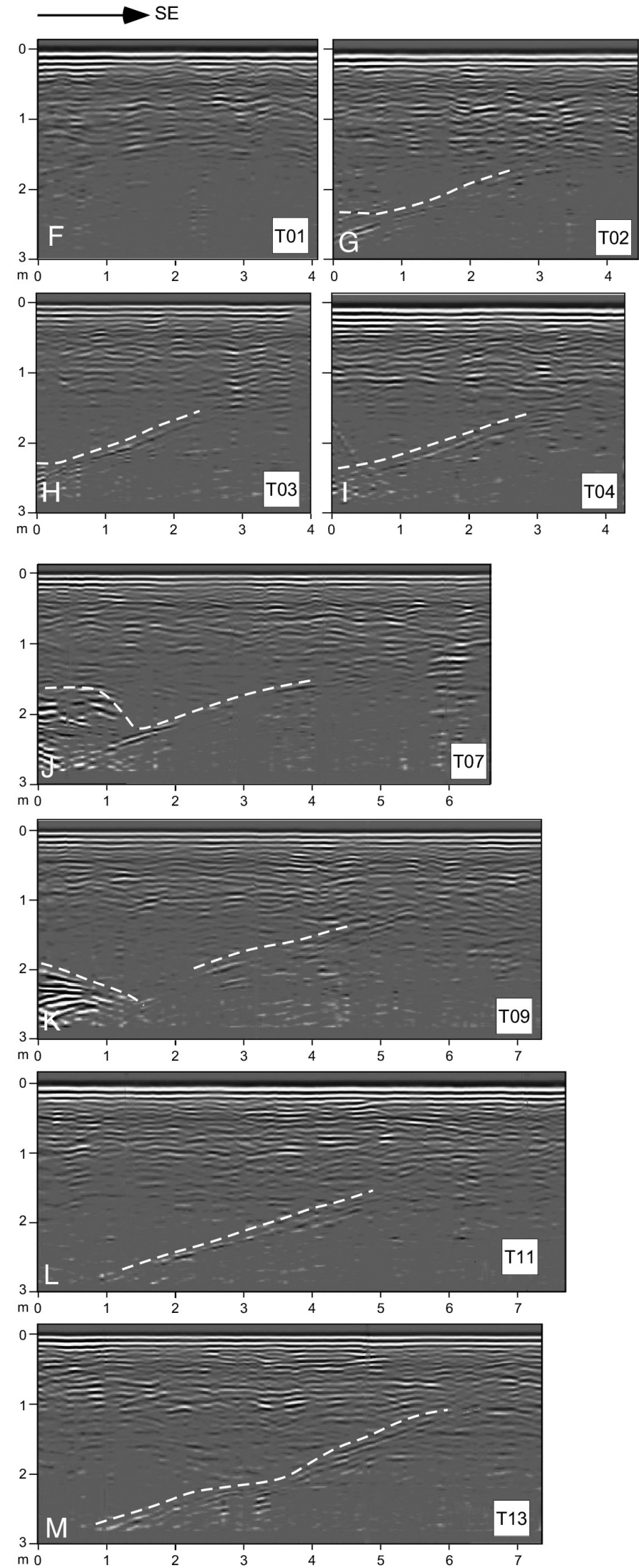

Fig. 12. A) Grid of the ground penetrating radar survey carried out on the flat floor in front of the slab pile on Site 6 (see Fig. 5A for location); $\mathrm{B}$ to M) Longitudinal (L01 to L06) and transverse (T01 to T13) sounding profiles. 


\section{DISCUSSION AND CONCLUSION}

Combined radiocarbon dating of charcoal remains from three fireplaces in Sala del Fuoco of the Grotta del Fiume Cave indicates that this hypogeal environment was visited by humans some 16,201 \pm $198 \mathrm{yr}$ BP, while a fourth fireplace in the same room yielded a slightly older age of $16,779 \pm 221 \mathrm{yr}$ cal. BP. Therefore, these dates with their $2 \sigma$ analytical uncertainty suggest that this cave room was visited by man through a period between about 17,000 and 16,000 years ago. In the climatic event-stratigraphy model of Rasmunsen et al. (2014), this millennium falls within the cold Glacial Stadial 2.1a (GS-2.1a) in the Last Glacial period, practically corresponding to the so-called Oldest Dryas event, or the Gschnitz Stadial in the later part of the European Würm glaciation, which shortly followed the maximum extent of continental glaciers (LGM) in the northern hemisphere between 26,000 and 19,000 years ago. In the Greenland oxygen isotope record of ice cores GRIP, GISP2, and NGRIP, the cold event GS-2.1a ends with a sharp positive $\delta^{18} \mathrm{O}$ shift at 14,700 years BP to mark the beginning of the temperate (warmer) Glacial Interstadial 1e (GI-1e; Rasmunsen et al., 2014), which is equivalent to the Bølling climate oscillation. During the GS-2.1a period, the Umbria-Marche region was not glaciated at altitudes lower than $1,500 \mathrm{~m}$ asl. Presumably it was a time of generalized periglacial, dry and cold environmental conditions with scarce arboreal coverage (e.g., Ravazzi et al., 2007), which, in any case, was preferentially localized along aggrading river valleys, streams, and wetlands. At present, there are no palynological data available in literature that could give some insight on the paleoenvironmental conditions in the Frasassi area during the millennium 17-16 ka. Eventually, a paleobotanical analysis of the charcoal remains in Sala del Fuoco may provide some discernment on the type of wood that was used to lit the fires in this cave so to give an idea of the type of vegetation growing in the Frasassi gorge at that time.

Nevertheless, the analysis of a stalactite from Grotta Grande del Vento (sample NIA-1 in Kudielka et al., 2019), which yielded a high resolution oxygen and carbon stable isotope record calibrated with several U-Th dates, indicates that a sharp negative $\delta^{18} \mathrm{O}$ shift occurs in the millennium 18-17 ka, thus a thousand years before the period of human frequentation in Sala del Fuoco, but also some 2-3 thousand years before a similar sharp $\delta^{18} \mathrm{O}$ shift recorded at $\sim 15 \mathrm{ka}$ in the Greenland ice cores (Rasmunsen et al., 2014, and references therein). The apparent diachronism of this sharp climate change as recorded in speleothems, has been observed in other caves around the world. In the Soreq Cave in Israel, for instance, the $\delta^{18} \mathrm{O}$ negative shift is recorded in the millennium 19-18 ka (Kudielka et al., 2019, and references therein), whereas in the Hulu Cave in China, a similar isotopic shift was dated at about 15-14 ka (Wang et al., 2010), thus consistent with the Greenland ice cores. An eventual high resolution integrated analysis of the stump of the fallen stalagmite SDF-fstg83 described above (see Fig. 11), which would combine U-Th dating and clumped isotope analysis, will give a precise date for the climate change and a better determination of the environmental conditions (i.e., ambience temperature) of the cave when it was frequented by man in the millennium 17-16 ka.

Whatever the climatic-environmental condition in the Frasassi Gorge was in the millennium 17-16 ka, the cozy Sala del Fuoco room must have provided an exclusive environment for the few Epigravettian hunters who used it for some special occasion rather than daily residential purposes. For one thing, the vast flat-bottomed Sala del Fuoco room opens up in the underground at the end of a $30 \mathrm{~m}$ long, curved cuniculus (see Site 9B in Fig. 5A), which would have blocked any thread of daylight, leaving the room in absolute darkness. Therefore, the hunters must have brought in dry wood and the supplies necessary to light a main bonfire in a well-ventilated spot at the foot of an imposing giant stalagmite (the Totem). But in order to reach the fireplace, they had to walk $40 \mathrm{~m}$ from Site 8A (the inner end of the entrance tunnel) to Site 1, watching their step, and so they must have had some sort of torches to see where they were putting their feet in that dark, spooky underground environment. The charcoal traces found in sites $1 \mathrm{~A}$ and $1 \mathrm{~B}$ may represent the leftovers of these torches and they yielded radiocarbon dates indistinguishable from the main fireplace and the juvenile ibex of Site $8 \mathrm{~A}$. It remains unsure whether the age of the fireplace in Site $1 \mathrm{C}$, with its radiocarbon date several centuries older than the mean age of the other fireplaces, hides an accuracy error or possibly that the dry wood used to light that particular fire was much older than the wood used for the other fires.

Many decorated deep caves in northern Spain and southern France, which required fire lightning to illuminate the otherwise pitch-black environment, witnessed groups of Upper Paleolithic people repeatedly gathering in there to perform, besides parietal art, all sorts of hypothetical social, cultural, or religious activities and rituals leaving behind remains of combustion, stone stacking structures, and intentionally deposited materials and objects (e.g., Medina-Alcaide et al., 2018, and references therein). Contextually, our undecorated but equally deep and dark Sala del Fuoco cavern only exhibits evidence for a few fire lighting, a few bones of ibex probably eaten on site by man, and four lithic artifacts crafted from local chert. In addition, a seemingly unnatural pile of speleothem slabs may represent a stacking structure. The questions that ask for rational answers are now: 1) how many people have used Sala del Fuoco in the millennium 17-16 ka or possibly in the four centuries between 16.4 and 16.0 thousand years ago? 2) how many times?, and 3) for what reason? Judging from the three ibex individuals identified so far in this cave, i.e., the old female specimen reported by Coltorti \& Sala (1976) in Sala delle Ossa, the adult male set on the tip of a stalagmite near the main fireplace as reported by Antonini (1986), and the juvenile specimen here identified in the bone deposit of Site $8 \mathrm{~A}$, leads us to speculate that a couple of dozen or so hunters would have been able to eat all that game 
meat (i.e., about $200 \mathrm{~kg}$ in total). However, it may well be that these three ibex specimens were killed in three different hunting parties by smaller hunting bands more likely composed of a few individuals. Shedding some light on the question of how many times small groups of Epigravettian hunters have visited this cave would require an archeological excavation of the main fireplace in Site 1 and also the fireplace of Site 1C, which can be carried out only by specialized personnel with the required by-law authorization of the regional Archeological Superintendence.

As for the question of why these hunters ventured in this cave bringing in big hunted game and wood for lighting fires instead of bringing the catch of the day to their settlement, whether a camp or a hut village down in the valley, or a more comfortable and easy-to-reach cave in the crags of the Frasassi Gorge, the most plausible explanation is that they gathered there to perform some sort of a ritual or ceremony. Not excluding that it may have been like a fraternity party for an initiation to adulthood or leadership, one possibility is that small groups of hunters were gathering there to worship either a deity or a dead fellow. A funeral worship scenario is suggested by a seemingly unnatural deposit of speleothem slabs piled up in Site 4 among collapsed boulders, which may represent a burial earthen mound. However, the only way to test this hypothesis will be to remove the slabs, an operation that requires, once again, specialized archeological personnel and the authorization of the regional Archeological Superintendence.

In conclusion, our non-invasive environmental study of the Sala del Fuoco cavern and the geochronological assessment via radiocarbon AMS dating of charcoal remains and ibex bones found therein, lead us to the hypothesis that this hypogeal space was seldom visited, in the late Upper Paleolithic (17-16 ka), by small groups of hunters for ritual and possibly funeral purposes. Further on-site research, which implies archeological digs by specialized personnel with the by-law authorization of the regional Archeological Superintendence, will hopefully verify our hypothesis and in any case shed more light on the Epigravettian culture in this region of central Italy.

\section{ACKNOWLEDGEMDENTS}

This work was financed by the Association "Le Montagne di San Francesco" and the Geological Observatory of Coldigioco. We would like to thank cavers Simone Cerioni, Maxwell Montanari, Daniele Ferranti, and Roberto Cingolani, for technical support in earlier expeditions in Sala del Fuoco, Mauro Bolognini for finding the sample of cooked clay on Site 11, Klaas van der Borg (Utrecht University) for letting us publish his results of the first ${ }^{14} \mathrm{C}$ AMS dating of the main fireplace charcoal, speleo-archeologist Daniele Visentin (University of Ferrara) for visiting with us Sala del Fuoco and sharing his opinions on our archeological interpretations, Benedetto Sala (Paleontology and Prehistory Museum of Ferrara) for a first inspection of the ibex bones we collected from Site 8A, and Giuseppe Antonini (GSM Ancona) for sharing with us his remembrances of the discovery of Sala del Fuoco in 1986. Last but not least, we would like to thank Prof. Bogdan P. Onac the editor of the International Journal of Speleology and two anonymous reviewers for having reviewed critically yet constructively the original draft of this paper allowing us to improve its form and archeological correctness.

Authorship statement: AM designed and directed the study, participated in some sampling campaigns, and wrote the paper with input from all authors. AA performed the TLS survey. AC performed the GPR survey. MPF examined and classified the ibex bones; MM led all the sampling campaigns and performed the mapping of the cave. SM participated in most sampling campaigns and performed the mapping of the cave; DM performed the U-Th analysis of speleothems. GP examined and classified the chert artifacts; SR participated in all sampling campaigns performing the photographic documentation.

\section{REFERENCES}

Antonini, P., 1986. Report on paleontological finds. Archived document Pos. ZA/20/15 Prot. 9212, Soprintendenza Archeologica delle Marche, Via Birarelli 15, Ancona, Italy.

Arias, P., 2009. Rites in the dark? An evaluation of the current evidence for ritual areas at Magdalenian cave sites. World Archeology, 41(2), 262-294.

https://doi.org/10.1080/00438240902843964

Bartolomei, G., Cattani L., 2005. La fine dell'ultimo glaciale nella valle dell'Esino, Jesi, Ancona: considerazioni paleoecologiche. In: Atti della XXXVIII Riunione Scientifica Preistoria e Protostoria delle Marche, Portonovo, Abbadia di Fiastra, October 1-5 2003, Istituto Italiano di Preistoria e Protostoria, Roma 2005, 1, 103-115.

Bazzanella, M., 2005. L'industria in materia dura animale dal sito di Riparo Dalmeri (Selva di Grigno, Trento): analisi tipologica e distribuzione areale. Preistoria Alpina, 41, 199-229.

Bocchini, A., Coltorti, M., 1978. Rilievo topografico e geomorfologico del complesso carsico Grotta del Fiume (8 MA - AN) Grotta Grande del Vento (307 MA - AN). In: Atti XIII Congresso Nazionale di Speleolologia, Perugia September 30 - October 4, 1978. Gruppo Speleologico CAI, Perugia, Italy.

Bocchini A., Coltorti, M., 1990. Il complesso carsico Grotta del Fiume - Grotta Grande del Vento e l'evoluzione geomorfologica della Gola di Frasassi. Memorie dell'Istituto Italiano di Speleologia, 4, 155-179.

Broglio, A., Coltorti, M., Peresani, M., and Silvestrini, M., 2005. Il Paleolitico delle Marche. In: Atti della XXXVIII Riunione Scientifica Preistoria e Protostoria delle Marche, Portonovo, Abbadia di Fiastra, October 1-5 2003, Istituto Italiano di Preistoria e Protostoria, Roma 2005, 1, 27-61.

Cattuto, C., 1976. Correlazione tra piani carsici ipogei e terrazzi fluviali nella valle del Fiume Esino (Marche). Bollettino della Società Geologica Italiana, 95, 313-326.

Cheng, H., Edwards, R.L., Shen, C.-C., Polyak, V.J., Asmerom, Y., Woodhead, J., Hellstrom, J., Wang, Y., Kong, X., Spötl, C., Wang, X., Calvin Alexander, E., 2013. Improvements in ${ }^{230} \mathrm{Th}$ dating, ${ }^{230} \mathrm{Th}$ and ${ }^{234} \mathrm{U}$ half-life values, and $\mathrm{U}-\mathrm{Th}$ isotopic measurements 
by multi-collector inductively coupled plasma mass spectrometry. Earth and Planetary Science Letters, 371-372, 82-91.

https://doi.org/10.1016/j.eps1.2013.04.006

Coltorti, M., Sala, B., 1978. Resti fossili nella Gola di Frasassi. Natura e Montagna, 1, 27-31.

Coltorti, M., Lemorini, C., Peresani, M., Polzinetti, S., Pieruccini, P., Silvestrini, M., Zampetti D., 2012. La "Vénus offrant" de Frasassi (Italie centrale): un nouveau type de statuette paléolithique. In: Clottes J. (Ed.) L'art pléistocène dans le monde / Pleistocene art of the world / Arte pleistoceno en el mundo, Actes du Congrès IFRAO, Symposium "Art mobilier pléistocène". Numero spécial de Préhistoire, Art et Sociétés, Bulletin de la Société Préhistorique Ariège-Pyrénées, 6566(400), 1275-1289.

Cremona, M.G., 2008. Strategie di sfruttamento delle risorse litiche nella prima parte dell'Epigravettiano Recente dell'Italia nord-orientale; Analisi tecnotipologica di un livello proveniente dall'area interna del sito di Riparo Tagliente: L'unità stratigrafica 13A ALFA. Unpublished PhD Thesis, Università degli Studi di Ferrara, Italy, $239 \mathrm{p}$

Edwards, R.L., Chen, J.H., Wasserburg, G.J., 1987. ${ }^{238} \mathrm{U}-{ }^{234} \mathrm{U}-{ }^{230} \mathrm{Th}-{ }^{232} \mathrm{Th}$ systematics and the precise measurement of time over the past 500,000 years. Earth and Planetary Science Letters, 81, 175-192. https://doi.org/10.1016/0012-821X(87)90154-3

Forestalp 1987. Report on the survey of Sala dello Stambecco and delivery of archeological finds. Archived document n. Pos. ZA/20/15 Prot. 8426, Soprintendenza Archeologica delle Marche, Via Birarelli 15, Ancona, Italy.

Forti, P., Galdenzi, S., Sarbu, S.M., 2002. The hypogenic caves: a powerful tool for the study of seeps and their environmental effects. Continental Shelf Research, 22(16), 2373-2386.

https://doi.org/10.1016/S0278-4343(02)00062-6

Galdenzi, S., 1990. Un modello genetico per la Grotta Grande del Vento. In: Galdenzi, S., Menichetti, M., (Eds), Il Carsismo della Gola di Frasassi. Memorie dell'Istituto Italiano di Speleologia, Costacciaro (Italy) 4, 123-142.

Galdenzi, S., Menichetti, M., Sarbu, S.M., Rossi, A., 1999. Frasassi caves: A biogenic hypogean karst system?. In: Audora, P. (Ed.), Proceedings of the European Conference Karst 99: Université de Provence, Études de Géographie Physique, 28, 101-106.

Galdenzi, S., Cocchioni, M., Morichetti, L., Amici, V., Scuri, S., 2008. Sulfidic ground-water chemistry in the Frasassi caves, Italy. Journal of Cave and Karst Studies, 70, 94-107.

Kudielka, G., Bar-Matthews, M., Gilmour, M., Ayalon, A., Koeberl, C., Montanari, A., 2019. Implications for central Italy paleoclimate from 95,000 yr B.P. until the early Holocene as evident from Frasassi Cave speleothems. In: Koeberl, C., Bice, D.M. (Eds.), 250 Million Years of Earth History in Central Italy: Celebrating 25 Years of the Geological Observatory of Coldigioco. Geological Society of America Special Paper, 542, 429-445.

https://doi.org/10.1130/2019.2542(24)

Laplace, G., 1964. Essey de la typologie systématique. Annali dell'Università di Ferrara, Sezione XI Paleontologia Umana e Paletnologia, Supplemento II, 1, 1-85.

Macalady, J.L., Lyon, E.H., Koffman, B., Albertson, L.K., Meyer, K., Galdenzi, S., Mariani, S. 2006. Dominant microbial populations in limestone corroding stream biofilms, Frasassi cave system, Italy. Applied and Environmental Microbiology, 72, 5596-5609. https://doi.org/10.1128/AEM.00715-06

Macalady, J.L., Dattagupta, S., Schaperdoth, I., Jones, D.S., Druschel, G.K., Eastman, D., 2008. Niche differentiation among sulfur-oxidizing bacterial populations in cave waters. The ISME Journal, 2, 590-601.

https://doi.org/10.1038/ismej.2008.25

Mainiero, M., 2003. Indagine mediante georadar eseguita nel Cimitero Israelitico - area Parco del Cardeto Technical Report for the Comune di Ancona, 60100 Ancona, Italy, 23 p.

Mariani, S., 2003. Indagini idrogeologiche e idrochimiche in un nuovo ramo della Grotta del Fiume (Frasassi AN): contributi della speleologia alla ricostruzione dell'evoluzione carsica e tettonica dell'area durante l'Olocene. Laurea Thesis, University of Camerino, $77 \mathrm{p}$. Mariani S., Mainiero M., Barchi, M., van der Borg K., Vonhof H., Montanari A., 2007. Use of speleologic data to evaluate Holocene uplifting and tilting: an example from the Frasassi anticline (northeastern Apennines, Italy). Earth and Planetary Science Letters, 257, 313318. https://doi.org/10.1016/j.epsl.2007.02.045

Medina-Alcaide, M.A., Garate-Maidagan, D., RuizRedondo, A., Sanchidrián-Torti, J.S., 2018. Beyond art: The internal archaeological context in Paleolithic decorated caves. Journal of Anthropological Archaeology, 49, 114-128.

https://doi.org/10.1016/j.jaa.2017.12.005

Montanari, A., Chan, L.S., Alvarez, W., 1989. Synsedimentary tectonics in the Late Cretaceous-Early Tertiary pelagic basin of the Northern Apennines. In: Crevello, P.D., Wilson, J.L., Frederick Sarg, J., Reed, J.F. (Eds.), SEPM Special Publication, 44, 379-399. https://doi.org/10.2110/pec.89.44.0379

Montanari, A., Mainiero, M., Mariani, S., Cerioni, S. Montanari, M., Curatolo, A., Pignocchi, G., 2017. A probable Paleolithic sanctuary in the Room of Fire of Grotta del Fiume at Frasassi (Marche, Italy). In: Book of Abstracts with Program, Geological Society of America Penrose Conference, September 25-30, 2017, Apiro (Italy), 92-93.

Montanari, A., Lüthgens, C., Lomax, J., Mainiero, M., Mariani, S., Fiebig, M., 2019. Luminescence geochronology of Pleistocene slack-water deposits in the Frasassi hypogenic cave system, Italy. In: Koeberl, C., Bice, D.M. (Eds.), 250 million years of Earth history in Central Italy: Celebrating 25 years of the Geological Observatory of Coldigioco, Geological Society of America Special Paper, 542, 411-428. https://doi.org/10.1130/2019.2542(23)

Mussi, M., Cocca, E., D’Angelo, E., Fiore, I, Melis, R.T., Rus, H. 2008. Tempi e modi del ripopolamento dell'Appennino centrale nel Tardiglaciale: nuove evidenze da Grotta di Pozzo (AQ). In: Mussi, M. (Ed.), Il Tardiglaciale in Italia: lavori in corso, British Archaeological Reports International Series, 1859, Oxford, 111-132. https://doi.org/10.30861/9781407303420

Parco Naturale della Rossa e di Frasassi, 2000. Il Mondo Sotterraneo. In: I Quaderni del Parco, Comunità Montana dell'Esino e di Frasassi, 160 p.

Pignocchi, G., 2015. La frequentazione delle grotte della Gola di Frasassi e della Rossa in età pre-protostorica tra ricerca archeologica e speleologica. In: Book of abstracts of the XXII Congresso Nazionale di Speleologia "Condividere i dati", Pertosa-Auletta (Salerno, Italy), May 30-June 2, 2015, 1-6.

Pignocchi, G., 2017. Archeometry of Late Paleolithic finds in the caves of the Frasassi area (Marche, Italy). In: 
Book of Abstracts with Program, Geological Society of America Penrose Conference, September 25-30, 2017, Apiro (Italy), 100-101.

Pignocchi, G., 2018. La frequentazione archeologica delle grotte nelle Marche. In: Boccuccia, P., Gabusi, R., Guarnieri, C., Miari, M. (Eds.), Proceedings of the conference titled "...nel sotterraneo Mondo", Federazione Speleologica Regionale dell'Emilia Romagna (Brisighella, October 6-7, 2017), 141-154.

Pignocchi, G., Montanari, A., 2016. La Grotta della Beata Vergine di Frasassi (Genga - AN): vecchi e nuovi dati geo-archeologici. Rivista di Scienze Preistoriche, 68, 143-180.

Ravazzi, C., Peresani, M., Pini, R., and Vescovi, E., 2007. Il Tardoglaciale nelle Alpi italiane e nella Pianura Padana. Evoluzione stratigrafica, storia della vegetazione e del popolamento antropico. Il Quaternario, 20, 163-184.

Rasmussen, S.O., Bigler, M., Blockley, S.P., Blunier, T., Buchardt, S.L., et al., 2014. A stratigraphic framework for abrupt climatic changes during the Last Glacial period based on three synchronized Greenland ice-core records: refining and extending the INTIMATE event stratigraphy. Quaternary Science Reviews, 106, 14-28. https://doi.org/10.1016/j.quascirev.2014.09.007

Silvestrini, M., Peresani, M., 2007. Baracche (Cingoli, Ancona). Rivista di Scienze Preistoriche, 57, 437-438.

Silvestrini, M., Ferraris, S., Peresani, M. 2005. La produzione laminare nella tradizione gravettiana: le officine litiche di Fosso Mergaoni (Valle dell'Esino). In: Atti XXXVIII Riunione Scientifica Istituto Italiano di Preistoria e Protostoria, 93-102.

Silvestrini, M., Cancellieri, E., Peresani, M., 2008. Madonna dell'Ospedale, un sito Epigravettiano Antico al Margine dell'Appennino Marchigiano: osservazioni sulla produzione litica. In: Mussi, M. (Ed.), Il Tardiglaciale in Italia: lavori in corso, British Archaeological Reports International Series 1859, Oxford, 81-102.

Taddeucci, A., Tuccimei, P., Voltaggio, M., 1992. Studio geocronologico del complesso carsico "Grotta del Fiume-Grotta Grande del Vento" (Gola di Frasassi, Ancona) e implicazioni paleoambientali. Il Quaternario, 5, 213-222.

Taddeucci, A., Tuccimei, P., Voltaggio, M., 1994. ${ }^{240} \mathrm{Th}$ dating of speleothems from the "Grotta del FiumeGrotta Grande del Vento" karst system in Frasassi (Ancona, Italy), and paleoenvironmental implications. International Journal of Speleology, 23, 79-90. https://doi.org/10.5038/1827-806X.23.1.10

Taylor, S.R., McLennan, S.M., 1985. The Continental Crust: Its Composition and Evolution. Blackwell Scientific Publications, Oxford, 312 p.

Valladas , H., Pons-Branchu, E., Dumoulin, J.P., Quiles, A., Sanchidrian, J., Medina-Alcaide, M.A., 2017. U/ Th and ${ }^{14} \mathrm{C}$ crossdating of parietal calcite deposits: Application to Nerja Cave (Andalusia, Spain) and future perspective. Radiocarbon, 59(6), 1955-1967. https://doi.org/10.1017/RDC.2017.120

Wang, Y.J., Cheng, H., Edwards, R.L. An, Z.S., Wu, J.Y., Shen, C.C., Dorale, J.A., 2001. A high-resolution absolute-dated late Pleistocene monsoon record from Hulu Cave, China. Science, 294, 2345-2348. https://doi.org/10.1126/science.1064618

Wegmann, K.W., and Pazzaglia, F.J., 2008. Late Quaternary fluvial terraces of the Romagna and Marche Apennines, Italy: Climatic, lithologic, and tectonic controls on terrace genesis in an active orogen. Quaternary Science Reviews, 28, 137-165. https://doi.org/10.1016/j.quascirev.2008.10.006 